\title{
Relationship or Boundary? Handling Successive Contracts
}

\author{
By Subha Narasimhan $\dagger$
}

\begin{abstract}
Although the ongoing relationship generated by successive contracts between two parties is quite similar to the relationship generated by a continuing contract that entails a series of consecutive obligations, it receives very different legal treatment. Professor Narasimhan argues that traditional contract law fails to protect adequately the parties' stake in successive-contract relationships against opportunistic behavior. In this Article, she analyzes the role that information plays in creating openings for opportunistic behavior and discusses the costs of failing to deter opportunism. Professor Narasimhan argues that, in the context of successive contracts, gaps in the information available to parties create much friction and foster the manipulative behavior which plagues continuing contractual relationships. She also analyzes the effect of the nature of the transaction and the level of party sophistication on these problems. Professor Narasimhan argues that a system of rules enforcing an obligation to renew contracts should be developed. She discusses three possible regimes-enforceable renewal clauses (opting in), implied renewal clauses (opting out), and mandatory renewal - and concludes that the regime that minimizes opportunism depends upon the level of party sophistication.
\end{abstract}

\section{INTRODUCTION}

To a large extent, contract law has treated contractual relationships as extending in time only between the formation and the termination (whether by successful performance or by breach) of a contract. Consequently, contract law has tended to draw sharp distinctions between one continuing contract governing a series of successive obligations-such as requirements and output contracts-in which long-term relational dependencies are recognized, and a series of contracts between the same parties governing successive obligations in which such dependencies are not recognized. ${ }^{1}$ Yet, the relationship and dependencies generated between the parties in these two situations remain similar in many important respects.

$\dagger$ Professor of Law, Columbia University School of Law. B.S. 1970, University of London; M.S. 1972, Ph.D. 1975, Stanford University; J.D. 1980, Columbia University School of Law. I would like to thank Professors Robert E. Scott and Kellis Parker for their helpful comments on earlier drafts of this article and Columbia Law School for its financial support.

1. Indeed a literature has developed around, in part, the manner in which contracting parties can use this disparate treatment to structure their relationships to minimize the risks of foreseeable 
The differing treatment accorded to these fundamentally similar transactions permits sophisticated bargainers to structure contractual obligations to achieve particular legal consequences. ${ }^{2}$ But the legal fiction of sharp boundaries between contracts governing continuing relationships may also give rise to unexpected results, generating unfairness, opportunism, and waste.

Most of the scholarly discussion of the problems of opportunism generated in continuing or repeated contracting focuses on sophisticated bargainers with large stakes in the relationship. In such cases, the parties may be expected to foresee the possibility of repeated dealings and the opportunism problems generated thereby and may be presumed to have sufficient investment at stake to consider these problems when their relationship begins. ${ }^{3}$ Consequently, sophisticated bargainers can use the variety of possibilities generated by the differing legal fictions to customize contracts using standardized terms. Such sophisticated parties, however, represent only one end of a spectrum of possible contracting parties.

In this article, I examine the problem of repeated contracting between parties. In Part I, I shall separate the contractual relationship into three periods: (1) The inception of the relationship-that is, the time the bargain for the initial deal is struck; (2) the period during the

opportunism. See, e.g., Joskow, Vertical Integration and Long-term Contracts: The Case of Coalburning Electric Generating Plants, 1 J.L. EcoN. \& ORG. 33 (1985).

This is not to suggest that the existence of prior contractual relationships is treated as wholly irrelevant. For example, a prior course of dealing is often relevant under current law in defining expectations and in interpreting the terms and scope of the obligation. See, e.g., U.C.C. $\$ 1-205(3)$. But prior relationships are not deemed to generate values and sources of opportunism that outlive contractually defined endpoints.

2. For example, parties may choose between supply and spot contracting to achieve particular results. See Joskow, supra note 1, at 58-60.

3. While most commentators on these problems assume that the parties do not know the exact value of the dependencies generated by continuing relationships, they do assume that the parties are acutely aware that the value of the dependencies will be significant. See generally Klein, Crawford \& Alchian, Vertical Integration, Appropriable Rents, and the Competitive Contracting Process, 21 J.L. ECON. 297 (1978) (the germinal article on the problems generated by "lock-in" effects, and the resultant effect on structuring relationships); Joskow, supra note 1, and Goldberg \& Erickson, Quantity and Price Adjustment in Long-Term Contracts: A Case Study of Petroleum Coke, 30 J. L. ECON. 369 (1987) (examples of the industrial organization literature the foregoing article has spawned); and Scott, Conflict and Cooperation in Long-Term Contracts, 75 Calif. L. REv. 2005 (1987) (relational contracting in light of information and enforcement problems). Much of this literature suggests that, under these stringent constraints, the parties are best situated to structure their relationships to minimize opportunism. Scott, supra at 2039-53.

In contrast, the debates over the desirability of regulating industries which cater to many users and which may require large aggregate sunk costs do not makc these assumptions. Instead, this literature examines particular types of long-term contracts to determine whether severc lock-in problems, leading to inefficiencies, will result if the contract terms are left to private contracting, See, e.g., Williamson, Franchise Bidding for Natural Monopolies - In General and With Respect to CATV, 7 BELl J. ECON. 73 (1976).

This Article draws upon the insights of both streams of scholarship, since they are both relevant and necessary to an understanding of all contractual behavior. 
initial contract when performance is due; and (3) the period after the termination of the initial contract during which further negotiations may occur to continue the relationship between the parties. ${ }^{4}$

In this Article, I also examine three types of opportunism-opportunism generated by informational problems, by relational values, and by market values-and the similarities and differences among thein in each period. I then coinpare these findings with the assumptions made in doctrines designed to police contractual opportunism, using a model of contracting in which only a fraction of initial contractors want to repeat. This model is furtler used to examine the effects of varymg degrees of party sophistication and of information available to the parties at the time of the initial contract. This analysis allows me to formulate some of the ways in which the current fiction of termination generates values leading to opportunistic behavior by the parties, and to examine the extent to whicl current policing doctrime can deter sucl1 behavior.

In Part II, I deinonstrate that although many of the informational asymmetries plaguing the inception of contracting are absent during negotiations for follow-up contracts, these periods are marked by opportunities for relational opportunism closely akin to those that arise during the period for contractual performance. This potential for relational opportunism in negotiating successor contracts-absent in initial bargaining - can lead to socially wasteful hold-up behavior. Yet, for most policing purposes subsequent negotiation and initial bargaining are treated identically. Thus, parties must often attempt to deter opportunisin in follow-up contracting by the way they initially structure their relationship. Where parties do not liave adequate information about possible follow-up contracting at the tine they negotiate the initial contract, they are unlikely to be able to avoid these problems of relational opportunisin.

Since informational probleins are quite likely where parties are unsophisticated, or have smaller amounts at stake in each contract, ${ }^{5}$ I argue in Part III that mandatory rules governing the negotiations and allocations of successive contracts might produce a net benefit by reducing opportunistic beliavior. Moreover, mandatory rules might be justi-

4. Of course, this framework is an over-simplification. For example, the parties may conduct negotiations for subsequent relationships during the performance period of the initial contract. Such negotiations create a further source of opportunism, since the parties may attempt to exploit the relational values created in the initial contract by linking performance under the first contract to higher prices in the second. $C f$. Austin Instrument, Inc. v. Loral Corp., 29 N.Y. $2 d$ 124, 272 N.E. 2d 533, 324 N.Y.S. 22 (1971) (subcontractor threatened to withhold delivery of contract goods unless payment was increased).

5. Where small amounts are involved, parties may decide that the costs of generating information about repeated contracts during initial negotiations outweigh the value of such information. See infra text accompanying note 62. 
fied in some instances for sophisticated parties. Such parties might sometimes prefer to engage in risky hold-up strategies to maximize individual gains at the social cost of fewer cost-effective repeat transactions. Mandatory rules encouraging repeat transactions may be justified where such individual profit-maximizing behavior diverges froin socially optimal behavior. I inake soine suggestions as to the form such mandatory rules might take.

I assume throughout this Article that the market in question is competitive (thick) both as to buyers and sellers, thus focusing this Article on the particular form of relational dependencies I seek to study, and the opportunisin problems generated thereby.

\section{OPPORTUNISM AND CONTRACTUAL RELATIONSHIPS}

\section{A. Sources of Contract Value}

Consider a contractual relationship between two parties as it evolves over time. First, the parties initiate their relationship by negotiating and entering their first contract. Second, they enter the period during which they perform their agreement. Finally, they negotiate again and conclude the terms under which they will continue their relationship beyond the period of the first contract. ${ }^{6}$ Each stage of the relationship is characterized by the presence of various forms of value that collectively form the "contract value" - the value of the contract to the parties. This article considers three coinponents of this contract value:

Informational values: A lack of information about contract risks may generate two types of value. First, one party may have access to information to which the other does not, and may use this knowledge to her advantage. I shall term this "asymmetric information." Second, both parties might make assumptions about contract risks that favor one party which are later determined to be false. I shall term this "risk information."

Market value: Contracts are usually negotiated for future performance. During the course of the contract, the price set in the contract for the contract performance is quite likely to diverge from the market price for the agreed-upon performance. I shall refer to this difference in price as the "market value" of the contract.

Relational value: As parties deal with each other, their relationship may begin to generate benefits to them beyond the market value of the contract services. Parties may, for example, confirm that their partners are reliably punctual or cooperative; or they might, at some cost, change

6. For simplicity I take the case where the next contract is entered into after the first is terminated. A more complicated scenario occurs when the parties enter into a separate agreement during the period of performance of the first agreement. See supra note 4. 
their procedures in ways which accoinmodate the idiosyncracies of their partners' product. I shall describe these benefits as the "relational value" of the contract.

Each of these values generates incentives for opportunistic behavior. The next Section examines the likelihood that opporturistic behavior will occur in each contracting phase and the policing doctrines ainied at controlling such opportunisn1.

\section{B. Contracting Regimes}

\section{Entering the Initial Contract}

Where the parties are contracting for the first tine, informational asyinnietries are the inost likely causes of opportunistic behavior. ${ }^{7}$ Since no contract exists, there can be no inarket value to exploit. Relational values have not yet been created by a course of contractual dealing, but they may arise from other sources and generate some possibilities for opportunistic behavior. For exanple, the parties might have had previous noncontractual dealings that render suspect the arm's length nature of the transaction. They might be close friends, or one party might be in a position of trust-for exaniple, his doctor-with respect to the other, enabling her to exert "undue influence"s over him. But even though these cases niay occur, they are hikely to be infrequent, especially in business settings.

Inforinational asymnietries, however, are pervasive at this juncture. Parties often have unequal information concerning both the nature and quality of the contract goods and services, and the nature and reliability of their putative contractual partner. ${ }^{9}$ They are also likely to have asymnetric inforination about the possibility of repeat transactions, and about any econonnies associated with repeating. For exaniple, a particular buyer might be aware that he is likely (or unlikely) to need repeat serv-

7. Other types of opportunism, not considered here, can influence contracting at the initial stage. Examples include opportunism attributable to market structure (monopoly and "unequal bargaining power") and to duress. Monopoly problems are policed by antitrust doctrines; problems of bargaining inequality are policed by unconscionability doctrines and regulatory solutions (e.g., consumer and labor contracts). Duress may be found when one party has a physical hold on the other.

Another possible source of opportunistic behavior may be found in precontractual behavior, to the extent the legal community recognizes that precontractual negotiations create some rights between the parties. So far, such rights have little recognition, although at least one commentator suggests that the process of negotiation should in some instances create substantive rights. See Farnsworth, Precontractual Liability and Preliminary Agreements: Fair Dealing and Failed Negotiations, 87 ColUM. L. REv. 217 (1987).

8. "Undue influence" is the name of the doctrine used to police attempts to exploit such preexisting relational dependencies. See E. FARNSworth, ConTracts $\S 4.20$ (1982).

9. Of course, informational problems may exist which are not asymmetric. These, however, will lead to opportunism at the later stage of performance. See infra text accompanying notes 20-21, and notes 50-51. 
ices; sellers, on the other hand, are likely to know the average repeat rate and the average savings generated by repeat transactions. These asymmetries are policed during this first phase by two sets of doctrines. The first set polices the nature and quality of information which must be provided during negotiations. These doctrines generally do not require any disclosure, but they do require that any disclosures made be accurate. ${ }^{10}$ The second set of doctrines polices the nature and quality of goods and services. These doctrines often supply an implied terin of minimum merchantable quality, in the absence of agreement to the contrary. ${ }^{11}$

\section{During the Contract}

There are several important sources of contract value, and hence potential for opportumism, in the period between the fornation of the first contract and the completion of perforinance under it. First, the market price of the contract services may change so that it deviates from the contract price, thus endowing the contract with a market value. Second, once perforinance begins under the contract, the parties may develop values and dependencies specific to the particular relationship. ${ }^{12}$ Third, informational values may be generated as unexpected events occur and expected risks assume magnitudes different from those expected by the parties when the contract was formed.

A contract's market value might be used to force the otherwise profiting party to change the contract terms. The other party could threaten to breach the contract unless the profiting party agrees to give up some amount less than the contract value. One rationale for awarding expectation damages, the usual damage remedy for breach, is that it deters this source of opportunism because it exactly equals the contract's market value. Thus, the damage remedy for breach polices a contract's market value. However, the award of expectation damages, when modified by the rules which limit awards for subjective and unforeseeable damage and which do not provide recovery for litigation costs, is an extremely limited mechanism for policing contract value opportunism. ${ }^{13}$

In addition to the damage remedy, contract law uses other means to police against exploitation of contract values. ${ }^{14}$ For example, the doc-

10. Analogously, government contractors must comply with the Truth in Negotiations Act, 10 U.S.C. § 2306a. See, e.g., United States v. Newport News Shipbuilding, 862 F.2d 464 (4th Cir. 1988); United States v. Pimentel, 810 F.2d 366 (D.C. Cir. 1987); Aerojet-General Corp. v. U.S., 546 F.2d 431 (Ct. Cl. 1976).

11. For example, statutes will often imply warranties of quality. See, e.g., U.C.C. $\S 2-314$.

12. See infra text accompanying notes $26-29$.

13. See generally Narasimhan, Modification: The Self-Help Specific Performance Remedy, 97 YALE L.J. 61, 65-70 (1987).

14. See generally Muris, Opportunistic Behavior and the Law of Contracts, 65 MiNN. L. REV. 521 (1981) (some ways in which contract doctrine may be directed towards deterring opportunism). 
trines governing modification seek to limit the extent to which parties can exploit their partners' vulnerability by forcing a midstream reallocation of contract risks. ${ }^{15}$ Parties must justify any changes in contract ternis during the perfornance period before they can be enforced. Thus, in theory, the parties cannot change the price of a contract in midstream to reallocate the contract value.

Any policing of contract risks, however, must confront a basic tension in contract doctrine: What is the legal value of a contract? Modification doctrine suggests (though somewhat unsuccessfully) that contract values include both relational and market values. Consequently, modification doctrine implies that perfornance is the key to adequate contractual behavior, and that inadequacy of the damage remedy justifies a party's decision to modify a contract in order to induce adequate performance by the other party, even though the party has no intention of honoring the modification.

In contrast, reinedy doctrine nornially compensates breach with substitutional relief deternined by market values. Reinedy doctrine thus suggests that, except in the most unusual circumstances, the value of a contract is determined by inarket value alone. ${ }^{16}$ To the extent that promisors are free to choose between perforinance and breach, reinedy doctrine protects only the contract's market value. After all, promisors can usually refuse to modify, breach, and pay only expectation damages (the market value portion of the contract value). ${ }^{17}$ If the contract is breached, relational values can be protected only if the breach is easily policed and proved, and the damage award is timely and adequate (it inust, for exainple, mclude the value of the relational benefits); or if the promisees have a realistic right to specific performance with the ability to ensure the continuing level of service.

But, even if the promisors do modify the contract and perforn, the current policing of modifications is inadequate to ensure the protection of relational values. Modification doctrine would protect relational and other non-market values only if it provided a separate route and entitlement to specific perfornance (if parties could be coinpelled to modify and perforn rather than breach) and if any additional price for "unforeseen" work were adequately policed to ensure that it did not contain any

15. Most policing doctrines for economic duress fall into the category of preventing the exploitation of continuing contractual relationships, i.e., relational opportunism. Thus, duress usually consists of a threat not to perform on a contract in order to modify the contract terms. See, e.g., Selmer Co. v. Blakeslee-Midwest Co., 704 F.2d 924 (7th Cir. 1983) (defendant allegedly withheld payment in order to force settlement of a cost dispute); Astley v. Reynolds, 2 Strange 915 , 93 Eng. Rep. 939 (K.B. 1732) (pawned goods withheld to induce payment of excess interest), or to influence the partner on another contract, see, e.g., Austin Instrument, Inc., supra note 4.

16. See Narasimhan, supra note 13 , at 65-70.

17. For a more complete exposition of this anomaly see Narasimhan, supra note 13, at 65-68. 
component of payment for existing contract values. However, modifications are enforceable as long as "reasonable" changes are made in response to "unforeseen" risks. ${ }^{18}$ Two factors currently render this policing inadequate. First, if the party has prepaid, there is a good chance that it will not recover the excess payment since modification doctrine governs enforceability, wliile the recovery of excess payments may have to meet the more stringent requirements of economic duress, Second, and more importantly, to the extent the exploiter can change its services or point to unexpected circumstances, it will probably be allowed to enforce "reasonable" mcreases in price-which could well include the contract value-unless courts overcome their reluctance and scrutinize prices. For now, to the extent relational values predominate in a contract, parties may even be compelled to reallocate market value (which in theory is policed through the damage remedy) to preserve the noncompensable relational values. ${ }^{19}$

Informational value, the third type of value generated during the contract, is minimally policed due to yet another fiction: that contracts are allocations of risk, and that all risks are allocated at the inception of the contract. It follows that except for informational asymmetries at the bargaining stage that generate value during the contract, the law assumes that few additional informational values are generated during the contract. Thus, if the parties discover that the contract goods are in very short supply, or that the contract services are much more difficult to provide, the law presumes, in general, that no informational changes have occurred beyond the actual outcome of a projected and allocated risk. ${ }^{20}$ Some limits are placed upon this heroic assumption, and relief from contract enforcement may be granted in extremely limited circumstances. ${ }^{21}$

18. These requirements are inconsistent with the premises underlying contract enforcement, since they permit modification on the theory that risk allocation was incomplete, yet operate in a regime that generally assumes that risks have been completely allocated by the parties. See Narasimhan, Of Expectations, Incomplete Contracting, and the Bargain Principle, 74 CALIF. L. REV. 1123, 1183-86 (1986).

19. Contract value reallocation is policed in theory by modification doctrine (if the promisor agrees to modify and then performs) since the modification will not be enforced after performance unless it is a reasonable response to an unallocated risk. Given the inadequacies of legal policing of contractual performance, commentators have suggested that for sophisticated planners the most important sources of deterring relational opportunism lie outside the legal framework. See, e.g., Klein, Crawford \& Alchian, supra note 3, at 298-307; Scott, supra note 3, at 2039-53.

20. Thus, contracts are usually enforced despite such changes because the parties can provide against them in the contract. See Wills v. Shockley, 52 Del. 295, 296, 157 A.2d 252, 253 (Del. Super. Ct. 1960).

21. Examples include frustration, when the contract has become totally useless to one of the parties; impossibility, where performance has become almost totally impossible because of the occurrence of some event; and mistake, where the parties contracted under totally mistaken views as to the nature of the contract goods and services. See generally E. FARNSWORTH, supra note 8, at 647-705.

The doctrine of modification, discussed supra text accompanying notes $15-19$, does not provide 
During the contract, therefore, policing focuses mainly on attempts to exploit the market value of the contract. Some (but not much) attention is also given to policing certain aspects of relational and informational values.

\section{Subsequent Contracts Between the Same Parties}

In the absence of a regulatory regime that governs the relationship, parties are generally treated as if the scenario under which the subsequent contract is negotiated is a replay of the first negotiation. Thus, the law assumes that market value and relational opportumism may safely be ignored, and that mformational problems predominate. This approach is obviously valid for market value opportunism, but it is incorrect as to relational and informational opportunism. Contract law does rely to some extent on understandings generated im continuing relationships im order to imterpret ambiguous or murky terms. ${ }^{22}$ But contract law ignores whether, and to what extent, prior relationships create relational values, which generate opporturnities for one party to secure terms better than it could have obtained in the absence of such a relational background.

If the prior course of dealing creates values or efficiencies which can be realized only by continuing the particular relationship, the subsequent bargain cannot be viewed as an "arm's length" transaction in the same manner as the initial deal. At the same time, the learning generated during the performance of the initial contract will ameliorate some of the informational problems and asymmetries which beset the initial transaction. The particular relationship, in short, now has some aspects of bilateral monopoly similar to those in the modification situation, while in other respects (inost notably in the absence of a "market value") it resembles the initial situation.

These are not novel observations. Some of these concerns partially underlie the arguinents about the desirability of regulating some types of long-term relationships. ${ }^{23}$ But these concerns have not penetrated the general law of contracts. It may be that the primary focus on policing market value rather than relational values, even within existimg contracts, has contributed to this oversight.

I have hitherto argued that negotiations for continuing contractual relationships beyond the termination date of an existing contract will be marked by opportunistic attempts to exploit continuing relational values.

an avenue for limiting opportunistic behavior generated by additional informational value, since modifications must first be achieved through consensual means. However, if the party handicapped by the new information can compel its partner to modify, through exploitation of contract or relational values, the informational change might permit the handicapped party to enforce the modification. See Narasimhan, supra note 13.

22. Note the probative value accorded a "course of dealing" in U.C.C. $\$ 1-205$.

23. See, e.g., Williamson, supra note 3 , at 83-89. 
Yet, current policing doctrine by and large ignores the reality of continuing relational values and their attendant openings for opportunism and treats subsequent contracting as though it were an initial agreement. The remainder of this Article undertakes a systematic analysis of the differences between negotiating the initial contract and negotiating subsequent contracts. My emphasis will be on the values that exist in such a continuing relationship, and the ways in which they may be exploited during negotiation. Each disparity in the legal treatment of the value of a contract creates the potential for opportunistic behavior, as either party may attempt to use the disparity to its benefit and to the detriment of its partner. Similarly, every time we ignore the existence of real values in contractual relationships, we create new avenues of opportunism.

Of course, any adequate system for policing contractual opportunism must come to grips with the problems of policing relational values during contractual performance as well as those involved in repeat contracting. ${ }^{24}$ The debate on how best to police contractual performance is already underway on several fronts, however, and will not be treated further here. This Article will focus instead on introducing the relational problems of repeat contracting.

II

\section{OPPORTUNISM AND THE SECOND CONTRACT}

\section{A. Introduction: The Problem of "Lock-in" Effects}

What then are the differences between the situations of the parties at the initial contracting stage and at later contracting stages? It is intuitively plausible to suggest that information asymmetries-concerning, for example, the quality of the product ${ }^{25}$-are less likely to occur at the second negotiation. But this increased knowledge and confidence in one's contracting partner may generate a different problem. To the extent that a party has increased confidence about the contracted-for services, those services increase in value. This additional value can only be realized by entering into a repeat contract with the same party. Goods or services which were initially purchased in a competitive market of fungible products have become differentiated, ${ }^{26}$ and the parties are

24. See supra text accompanying notes 13-15.

25. Thus, at the stage of the second contract it could be inferred that the second contract contains a warranty that the products remain of the same quality as those supplied under the previous contract. It is equally plausible to suggest that "mistake" as to the nature or quality of the product is far more unlikely to occur at the second negotiation.

26. The degree to which this occurs would vary according to the complexity of the product and the relative mixture of goods and services. However, most products do generate some relational values. For example, people often buy the same brand of highly fungible products. Of course, many product markets cannot distinguish between repeat and first-time purchasers, and thus cannot discriminate in price between the two groups. It is therefore difficult to know the premitim, if any, 
now "locked in" to each other if they want to exploit the increased value of the contract goods. ${ }^{27}$

Lock-in probleins occur in subsequent dealings whenever (1) the existence of a prior contractual relationship creates a value which the parties can exploit only if the relationship continues, and (2) either or both of the parties want to exploit the value. This can occur in inany ways. For example, the parties may acquire information about each other's businesses while performing the initial contract that allows them to perform a second contract with each other inore efficiently than they could with a new partner. ${ }^{28}$ Alternatively, the initial relationship might have entailed a relation-specific start-up cost which is not transferable to other relationships. ${ }^{29}$ In that case, switching to a new contractual partner would entail abandoning the investment nade in the old relationship and retooling to meet the needs of the new partner. Thus, lock-in effects-real costs that will be faced by contracting parties if they switch to new partners-are prevalent not only during the performance of a contract, but also durmg negotiations to continue the contract relationship. It then becomes appropriate to ask how such lock-in effects influence negotiations for subsequent contracts between the same parties.

\section{B. Negotiating the Second Contract}

The discussion above suggests that relational values can lead to lock-in problems during the negotiation of continuing relationships between parties. The factors creating lock-in effects can be both extreinely varied and extremely complex. Consequently, I shall use a simple model involving sales of services by one seller to several buyers to

which could be charged for such "habit" buying. The product's price, though, would reflect the effects of the competitive market with one-sided information-all users would share in economies generated through repeat purchasers. See infra text accompanying notes 44-48.

27. This problem is identified and discussed in the context of the period for contract performance in Klein, Crawford \& Alchian, supra note 3, at 298-307. The authors refer to such relation-specific sunk investments as "appropriable quasi rents," and discuss the opportunism generated by the existence of such values where legal remedies for breach are insufficient and/or costly.

The authors conclude that these problems, when identified before the initial deal is made, (1) will lead to contract structures which minimize dependence on the legal system for enforcement (this frequently requires socially wasteful investment in reputation signals or in alternative arrangements to minimize the consequences of opportunism), and (2) may lead to ex ante choices as to the structure of the relationship (for example, between vertical integration and long-term contracting).

28. While the magnitude of this "learning by doing" advantage varies with the complexity of the required services, the existence of this value is quite common. An example is the advantage enjoyed by any employee who is familiar with her employer's filing system or organizational structure.

29. Consider, for example, a business which installs a word processing system. Once it has trained its employees to use one system, it will be quite reluctant to switch to another. This form of relational dependence, which involves non-transferable sunk investments, is of primary concern in the regulatory literature. See, e.g., Williamson, supra note 3. 
analyze the problem and demonstrate its probable ramifications. I shall assume that the only relational values which hold over beyond the performance period of the initial contract are those that affect the seller's performance. The seller learns facts particular to each buyer in the course of performing an initial contract that are necessary for successful performance. Each buyer's business is unlikely to change in ways which would render that information obsolete during the second contract. Thus, the seller may use the knowledge gained in the initial contract in performing subsequent contracts with the same buyer; consequently, the seller's cost of rendering subsequent performances will be reduced by the investment initially needed to generate the necessary information. Moreover, the model assumes that information obtained regarding each buyer is useful only in performing services for that buyer.

Consider, therefore, a seller who initially enters into contracts with ten buyers. The seller charges the buyers price $P$ if they enter into only one transaction with her. But, the cost to the seller of performing a second contract with any of its initial customers will be lower than the cost of performing the first because of the economies of continuing the relationship. ${ }^{30}$ Assume that two of the buyers will enter into a second contract with the seller, and that the cost to her of performing a second contract is $\$ 10$ less than the initial cost. The two continuing relationships therefore generate a savings value of $\$ 20$ to allocate over the ten relationships. Although this value is specific to a particular buyer-seller pair, the $\$ 10$ saved on each second contract need not be allocated between the parties to that particular contract. In the absence of legal constraints, the allocation is likely to depend upon the extent to which the parties are aware of that value and the competitiveness of the market at the time of the initial contract. ${ }^{31}$ Since the model assumes a thick market, the rest of this discussion will focus on the effects of information about value.

\section{Perfect Information}

Assume that at the time of the initial contracts all the parties not only know about the $\$ 10$ savings on each repeat contract, but also know exactly which parties will repeat. It is then possible for the seller to discrimimate among the buyers, and for repeat buyers, representing two potential sales, to negotiate for favorable treatment at the time of the first contract. The one-time buyers are likely to have to pay a price of $P$; the two potential repeating buyers are likely to pay a price between $\mathbf{P}$ and

30. See supra notes 25-29 and accompanying text.

31. Since the savings can be exploited only by the particular buyer-seller pair who have dealt before, the situation at the time of the second contract is necessarily monopolistic. 
P-10, with the premium for repeating divided in some way between the two contracts.

Arguably, almost the entire repeat value of $\$ 10$ will eventually be allocated to the repeat buyer. After all, the seller is willing to make deals at the profit margin generated by initial sales competitively priced at $\mathbf{P}$; each repeat buyer represents two sales at a total price of $2 \mathrm{P}-10$. The "extra" \$10 profit should be competed away to achieve the sale. But the timing of the payout generates problems of opportunism that will affect the distribution of the $\$ 10$ and possibly impede agreement. Since buyer and seller must stay together to generate the savings, each must ensure that the other does not terminate the relationship after the initial contract. The seller must not allocate the entire $\$ 10$ to the first contract; rather, she must carry enough of the discount over to the second contract to induce the buyer to stay in the relationship.

Nor will the buyer be willing to wait until the second contract to receive the $\$ 10$. The seller will then be in a position to insist upon a greater share of the $\$ 10$ than she could have obtained initially, since the buyer's only hope of receiving any part of the $\$ 10$ depends upon continuing the relationship with the seller. ${ }^{32}$ By the time the parties reach the stage of the second contract, neither the buyer nor the seller can exploit the savings without the other. While the buyer and the seller initially negotiated in a competitive market, they negotiate the second contract in a bilateral monopoly. This is highly analogous to their relationship during a contract. ${ }^{33}$

32. Consider what would happen if the seller were to give the buyer the entire $\$ 10$ at the initial stage: the seller has then made an investment of $\$ 10$ in the continuing relationship with the buyerone that can only be recouped by dealing with the buyer a second time. By the time the second contract stage is reached, the buyer could threaten to go with another seller at a price of $P$. The seller would then face a loss of the entire $\$ 10$ unless she could induce the buyer to remain in the relationship. The buyer would be able to extort an additional amount, up to $\$ 10$, from her. If, on the other hand, the entire $\$ 10$ is allocated to the second contract, the buyer has made a sunk investment in continuing the relationship and the seller gains bargaining power. The buyer could obtain only a price of $\mathbf{P}$ on the market-as the seller well knows. The seller can, therefore, insist on a price nearer to $P$ than she could have demanded initially.

This type of hold-up behavior is less likely to occur if both the buyer and the seller foresee further dealings (or other dealings) and hence foresee the need for cooperative behavior. But holdup behavior can be anticipated any time either the buyer or the seller believes an endpoint is imminent or that the gains derived from opportunism exceed potential gains from cooperation. See Klein, Crawford \& Alchian, supra note 3, at 304.

33. While the opportunism problem discussed here is similar to the analysis of appropriable quasi rents in Klein, Crawford \& Alchian, supra note 3, at 298-307, differences do exist. Appropriable quasi rents involve one party "owning" the rents-through an initial allocation of contract rights-and the other party acting opportunistically. Hence, the owner of the rents must devise ways to monitor and deter "cheating" by her partner.

Here, in contrast, the problems are those of defining the initial allocation, and generating the values. Both parties generate the values together, and both are locked in; neither has a property right in the value until it is allocated by them. Both need the other to create the property and the right, both need to deter cheating by the other, and both have incentives to cheat. 
A contract that covers the entire period may ameliorate this problem of distrust. A single contract signals that both parties mean to be bound for both transactions, and reduces the risk of opportunism that arises from deferring negotiations over the second transaction to the end of the first. Balanced against this is the increased risk of predicting market fluctuations and other performance matters, which arises from the himited information available to the parties at the time of the initial contract. Given the extent to which the fiction of completeness requires the parties to specify the details of their relationship, ${ }^{34}$ and the degree to which we adhere to the risk-shifting interpretation of contractual terms, the parties might be unwilling to specify their relationships for prolonged periods.

This analysis suggests that long-term contracts might be preferred for purposes of allocating relational surpluses and deterring relational opportunism, rather than as a means of allocating market risks. ${ }^{35}$ To the extent that this is so, parties faced with the possibility of a market-risk interpretation of their preferred arrangements inight look for strategies that will allocate relational values but not market risks. For example, provisions which defer the entire relational value to the second contract may be adopted, providing buyers with an option to renew the contract at the prevailing market price minus the relational value. ${ }^{36}$

Unfortunately, while a single contract might ameliorate the signalling and ex ante allocation problems, it leaves the parties exposed to relational opportumism within the contract. To the extent that either party has invested a part of the repeat savings in the relationship, the other may attempt, through renegotiation, to appropriate more than his or her agreed-upon share. Such opportunistic behavior is encouraged by loosely defined performance criteria. While such criteria permit the parties to adjust to the greater range of risks associated with longer term dealing, they also make it more difficult to determine whether breaches have occurred. This places the contracting parties in a serious quandary: $A$ rigid, long-term contract best deters relational opportunism, but it also exposes the parties to the problems created by the inadequate information that characterizes the initial negotiating period. ${ }^{37}$ If the parties are

34. Contract law presumes that parties allocate almost all risks in their contract, and that contract outcomes under almost any permutation of events can be determined from the terms of the contract itself. Traditional contract law therefore presumes that the contract is "complete" in its allocation of risk. See Narasimhan, supra note 18, at 1137-42, 1173.

35. The same thought underlies Professor Scott's observation that "[i]n many circumstances, therefore, the combination of the parties' desire to secure the benefits of long-term planning and investment, and their inability otherwise to reduce the vulnerability that such investment necessarily creates, will induce the parties to restrict themselves mutually by a long-term contract." Scott, supra note 3 , at 2011.

36. See Joskow, supra note 1.

37. See supra text accompanying notes 9-11. 
sophisticated and have sufficient resources, they can utilize various types of extra-legal policing; ${ }^{38}$ if they are not, significant possibilities emerge for wasteful opportunism.

\section{Almost Perfect Information}

Consider the "perfect information" scenario with one difference: Assume that although all the parties know that two buyers will repeat and hence generate a potential savings of $\$ 20$, they cannot identify who the repeat buyers will be. Thus, the seller cannot discriminate among the buyers at the time of the initial contract, nor can any buyer bargain on the grounds that he will be a repeat buyer.

The seller has $\$ 20$ that she can apportion either in some manner among the ten initial contracts, or between the two repeat buyers. What the seller will do is dictated by the competitive inarket for the initial contracts. She could, if she chose, simply include a renewal option at some price between $\mathrm{P}$ and $\mathrm{P}-10$ in the first contract. It would appear likely, given the competitive inarket for the initial contracts and the problems of opportunism that can arise, that the parties will prefer to allocate a large part of the $\$ 20$ to the ten initial contracts.

As in the perfect information case, ${ }^{39}$ the buyers would prefer to allocate the $\$ 20$ immediately for two reasons. First, since the probability of repeating is low, few buyers would want to defer receiving the repeat savings to the second contract on the chance that they will be one of the repeaters. ${ }^{40}$ Second, buyers would be most reluctant to delay the allocation of the savings over to the time when repeat dealings are negotiated, as the seller can then negotiate from a position of much greater strength. Conversely, the seller would prefer to wait to allocate the entire $\$ 20$ to the subsequent contracts since she can be sure that the repeaters will indeed repeat, and she will be in a superior position to bargain over the allocation of the $\$ 20$.

Again, since the seller is initially a fungible supplier, she will be forced to compete on the amount of the reduction she is willing to allocate to the first contract. Of course, the $\$ 20$ savings can only be achieved at the time of the repeat transaction, so she must retain sufficient incentive to ensure that the potential repeaters actually repeat with her. If she miscalculates and fails to provide sufficient incentive, a potential repeat buyer inay go elsewhere, thus reducing the savings generated by repeating-soine part of which the seller has already spent in inducing initial sales. The seller is, therefore, engaging in a form of deficit financing.

Notice, again, that if a buyer expects to repeat and desires to keep

38. See supra notes 19-27.

39. See supra text accompanying notes 32-38.

40. I am suggesting that most buyers are either risk-neutral or risk-averse. 
the entire repeat savings of $\$ 10$, he will be driven to signal his intentions by agreeing to a contract term covering the entire period. As before, the seller is unlikely to trust the buyer and allocate the amount to the initial contract; the buyer, on the other hand, would be exposed to opportunistic attempts by the seller if negotiations over the allocation of the savings were deferred to the second contract. Therefore, the parties are driven (as they are in the perfect information case) to a longer term contract with the attendant problems of inflexibility described above.

The foregoing discussion illustrates how informational problems can give rise to serious efficiency problems. To reap the full potential savings created by the efficiencies of continuing relationships, the seller must accurately walk a tightrope: She must retain enough of the $\$ 20$ savings to induce all potential repeaters to stay in a relationship with her while allocating enough of it to the initial contracts to maximize initial sales. Any defection automatically reduces relational savings; any error by the seller that results in a reduced number of repeaters results in a net loss in efficiency.

The seller could attempt to solve this problem by offering a renewal option at a lower than market price in the initial contract. However, to the extent that buyers prefer a lower average price and have the ability to prevail, the seller will not succeed. But added to this possibility is the price of distrust: If buyers believe that the seller may act opportunistically at the renewal stage, they will insist on a one-price alternative. ${ }^{41}$ Reputational constraints limit the seller's behavior to the extent that potential buyers are aware of how the seller treats her repeat buyers, and of the seller's history of opportunistic renegotiating behavior. ${ }^{42}$

If we compare this case to the one in which the parties possess complete information, we can see that the reduced information at the bargaining stage also has distributional effects. The inability to identify repeaters shifts the relational savings from the repeat buyers to all buyers. ${ }^{43}$ If the repeaters are the source of the savings, and only the absence

41. Unfortunately, the problem of mutual distrust is exacerbated by the current reluctance to enforce renewal obligations unless the terms of the renewal contract are sufficiently definite. See infra text accompanying notes 76-80. Moreover, the very uncertainty in the enforceability of a renewal term acts as an invitation for opportunistic behavior by the parties.

42. If a group of buyers, sufficiently large to police the seller market, learns of the seller's behavior and factors it into its decisions to deal with her, she will face reputational eonstraints on her opportunistic behavior. Reputation would also constrain the buyer's behavior, although it is less likely that sellers will have the necessary information before entering into an initial transaction with any given buyer. The extent of reputational constraints depends upon the nature of the market, the transaction (how much either party will invest in background information gathering), and the sophistication of the parties. See Schwartz \& Wilde, Imperfect Information in Markets for Contract Terms: The Examples of Warranties and Security Interests, 69 VA. L. REv. 1387, 1402-06 (1983).

43. This is especially likely when the probability of repeating is low, see supra text accompanying note 40; and when the seller's opportunism is encouraged by the current reluctance in contract law to enforce repeat obligations, see infra text accompanying notes 76-80. 
of information prevents them from enjoying those savings, it might be argued that they are entitled to all the savings, and that the legal regime should enable them to recover it. ${ }^{44}$

\section{One-Sided Information}

Consider now the possibility that the seller alone is aware at the time of the initial transaction that there will be relational savings associated with repeat transactions. ${ }^{45}$ What is the fate of the repeat savings of $\$ 20$ ? Two major possibilities exist: First, the repeat buyers become aware of the savings before negotiating the second contract; second, they do not. If we consider the seller and the buyers in isolation from the market, it might appear that the seller would be able to appropriate the full savings where the buyers are unaware of the savings, or a larger portion of the savings where the buyers only become aware of the savings at the subsequent contract stage. ${ }^{46}$

However, we are dealing with a competitive inarket. What are the seller's incentives for the use of the repeat savings that she retains? Even if the buyers never becoine aware of the relational savings, market forces still operate to force the seller to do exactly what she would do if the repeat buyers were aware of the savings, but not of the identity of the repeaters. Competition for custoiners will drive sellers to use the repeat savings to cut initial prices. Thus, the equilibrium price should approach the level set when the buyer knows of the relational savings when negotiating the first contract-the "almost perfect information" price. The seller must still correctly judge and allocate the amount needed to reduce the price of the repeat contracts to retain repeaters. This is particularly true when the buyer sees no benefit, beyond the decreased price, in retaining the seller to provide the services.

Compare to this the situation that obtains if the buyers do becoine aware of the $\$ 20$ savings before the repeat contracts are negotiated. The repeating buyers will want a much greater share of the $\$ 20$ than they would receive if they had remained ignorant of the savings. To the extent the $\$ 20$ is retained to allocate to the second contract, the repeat buyers are likely to want a larger portion. To the extent the seller has

44. The issue becomes whether the appropriate base line for determining property rights should be things as they are (status quo), or things as best we determine for social purposes. Since the repeat savings are attributable to a joint venture by the parties, any allocation between the parties would seem logically reasonable, thus giving a range of legal options over the property rights to the savings. See generally Singer, The Reliance Interest in Property, 40 STAN. L. REv. 614, 648-63 (1988).

45. See infra text accompanying notes 52-55.

46. If even a few buyers become aware of the savings at the subsequent stage, information may leak out to a sufficient number of initial buyers to police the market. See Schwartz \& Wilde, supra note 42 , at 1402-06. This then resembles the "almost perfect information" case, where the buyers would know of the existence of the relational bonus, but not of its distribution. 
already allocated the repeat value to initial contracts, the buyers are unlikely to believe her assertions as to the allocation. If they do believe her, they will still have an incentive for opportunistic behavior, since she has made a sunk investment in the second contract, and is vulnerable to that extent to threats by them to refuse repeat transactions.

Thus, in the case where buyers are unaware of repeat savings at the time of the initial transaction but later become aware of them, distrust and opportunism can generate significant bargaining frictions and inefficiencies. In fact, most cases will exhibit this problem. Furthermore, in most cases a repeat buyer will not know the amount of the savings to the seller, and this information defect will generate even more friction because, again, the buyer must either trust the seller or guess the amount of the savings. The seller may prefer (and may even be driven by the inefficiencies here) to let the buyers know about repeat possibilities at the negotiations for the first contract and then offer a renewal option, especially if buyers are more likely to trust the seller's word if she initiates this topic. The case would then parallel the full-information case.

Note that while fewer inefficiencies result when buyers remain unaware of repeat savings than when they eventually learn of the savings, the buyer-ignorance case presents special policing problems. As we have seen, if the market is competitive for initial sales, the buyers' lack of information is unlikely to translate itself into special gains for sellers, since the repeat savings are likely to be competed away by reducing prices to induce initial sales. The allocation of savings between repeat buyers and initial buyers is, however, significantly affected by lack of information. Opportunistic haggling over repeat values, at the risk of losing initial sales-a possibly significant social waste-is minimal, as buyers are unaware of their bargaining advantage.

However, inefficiencies due to the seller's need to correctly allocate repeat savings to maximize initial sales, without losing any repeat buyers, ${ }^{47}$ will remain. It is difficult to devise any policing scheme to minimize this problem. If buyers remain unaware that savings exist, they will be unable to police allocations made by sellers. Consequently, the public must police these transactions both as to detection and enforcement. But since it is highly unlikely that public policing will be worth the costs ${ }^{48}$ involved, sellers themselves probably will determine the extent to which such a rule will be enforced. To the extent that sellers see a joint interest

47. See supra text accompanying notes 39-41.

48. There are times where public policing might be worthwhile, including situations where large efficiency losses exist because of low repeat rates, or where sellers lock in unsophisticated buyers (even in competitive markets) by strategies which make repeat transactions expensive in order to reduce initial prices, as in the case of goods with low sales prices made up by large servicing or accessory charges. Such cases are often found in public consumer protection regulation. 
in allocating the value to maximize the number of initial sales, the result will be similar to the outcome where no policing rule exists.

\section{Imperfect Information at the Initial Stage}

In this case neitlier the seller nor the buyers know about the repeat savings at the imitial stage. This could liappen where neitlier party sees the need to consider the probleins of repeating. ${ }^{49}$ This is highly unlikely if the seller has dealt for soine time in the type of transaction at issue. It might occur if she introduces a radically different type of good or service and thus has no history of dealing from which to generate information, ${ }^{50}$ or if the buyer has an idiosyncratic need that distinguishes it froin other buyers and generates umque and unpredictable repeater values. ${ }^{51}$ In this case, it is unlikely that the seller will allocate the savings to all the buyers at the initial stage because she either does not know whether the savings will exist, or low great they will be. Since the seller has not invested in repeating by allocating a part of the repeat savings to initial contracts, she has more bargaining power over the terms of repeating than she has where she is initially aware of the savings.

Ignorance of the significance of repeating at the initial stage dramatically increases the probability of hold-ups at the second stage. Neither party can anticipate and reduce the type of hold-up beliavior that the repeat value will generate when it negotiates the repeat transaction; thus, neither party can avoid the opportunism probleins generated by relational values. In this situation, a rule imposing an obligation to repeat or requiring some particular allocation between the parties at the second contract stage might well liave the greatest payoff in efficiency, since it would reduce the scope for wasteful lioldups.

Note again, though, that this discussion applies only if both the

49. While this is quite likely where the parties do not consider themselves to be engaging in a "business" transaction (e.g., two friends agree to share an apartment, obtain a lease in one person's name, and then share the expenses of "doing up" the apartment), it also happens in business transactions. "Unsophisticated" business parties might not think through repeat problems, or might assume the good faith of their partners. An example is the dispute between the former operators of a Catskills fruitstand I used to frequent, and the farmer-owner of the property upon which the stand was located. For approximately fifteen years, the parties operated with year-to-year leases, with renewal negotiations centering upon the rent and the amount of the farmer's produce the operators were bound to accept. The stand became very successful. Suddenly, in 1987, the farmer simply refused to renew the lease because he wanted the stand for his children. Apparently, the lease had no clause requiring notice, termination, or buyout provisions. When I questioned the operators, who were excellent business people, they told me that it never occurred to them that the problem would arise.

50. Note, however, that relational problems might be exacerbated or swamped by real monopoly problems.

51. Repeaters will generally vary in the amount of value they generate; I suggest that the seller will assume and allocate some average value. Some buyers, however, may generate value which is significantly outside the usual range. 
buyer and the seller can see the potential for repeat savings at the renewal stage. If only one can, no opportunistic hold-up behavior will ensue, although we might still want to affect the distributional consequences of such one-sided information. But, again, any rule designed to facilitate private policing is likely to fail if the party who must police the contract fails to see the savings the rule is designed to police. Thus, in designing policing rules for repeat transactions, we must consider the effect of different types of repeating values.

\section{The Significance of the Nature of the Repeat Value for Relational Opportunism}

Two major classes of relational values are relevant to repeat transaction problems: those attributable to sellers and those attributable to buyers. Relational values attributable to sellers include an ability to perform repeat contracts at lower costs because fewer costs are incurred when repeating than when performing an initial contract. The seller, for example, may be more efficient in performing succeeding contracts with the buyer because she has made friends with his einployees or knows his corporate organization. Examples of values attributable to the buyer might include non-transferable sunk investments made by him in the seller's product (for instance, by training his employees or adjusting his processes to handle the seller's product).

While both types of savings are relationship-specific, they may lead to different consequences. For example, both parties are likely to be aware of the buyer's sunk costs at the initial stage and factor this into their initial bargain. The buyer, however, is less likely to see the cost advantage to the seller in repeating, especially when negotiating the initial contract. Differences in the outcome and the efficiency of the bargaining process are generated by, first, the different probabilities that the parties will recognize the values; second, the stage of the transaction when they recognize the values; and third, whether the information is one-sided (that is, only one party has information when the bargain is made). The possibility that the contracting parties are unsophisticated influences all three factors. The legal response to these problems should depend, therefore, on the nature of the savings, the relationship, and the parties.

\section{Savings Generated by Reductions in Seller's Costs}

Since the seller will have fewer costs when performing a second contract, continuing the relationship will generate repeat savings. If the seller is in the business of supplying the contract goods and has been doing so for some time, she slould be aware of these savings during the 
initial negotiations with the buyer. ${ }^{52}$ Whether the buyer will know, however, depends upon his degree of sophistication and the nature of the cost saving.

If the buyer regularly engages in the type of transaction at issue, ${ }^{53}$ or if the seller's start-up costs include a visible investment, the buyer is more likely to be aware of the seller's sunk cost, and hence of her vulnerability at the repeat stage. For example, the buyer will certainly know that the seller's repeat performance will cost less if she must build a plant to supply the product for the initial contract; less visible investments, however, such as reduced sales activity, or less investment in getting to know personnel or credit-worthiness ${ }^{54}$ make her vulnerability more difficult to discern. Moreover, the buyer (especially if unsophisticated) is less likely to be sufficiently interested in the possibility of a repeat transaction at the initial bargaining stage to consider it then. This could happen either because the probability of repeating for any given buyer is low, or the repeat value is low, or because an unsophisticated party would be unaware of the possibilities of opportumism at the stage of the repeat transaction.

As indicated earlier, in a competitive market the seller will attempt to use the repeat savings at the initial stage to induce first-tine sales, keeping only as much of the savings as required to induce the potential repeaters to repeat. The buyer who is aware of the seller's savings is likely, however, to want to appropriate the savings in the initial price, and then to indulge in hold-up behavior at the stage of the repeat negotiation. ${ }^{55}$ But the unsophisticated buyer, who cannot see that the seller lias invested in the repeat transaction, is unlikely to engage in the same type of behavior. The unsophisticated buyer, especially if the seller's savings are of the more subtle variety, is also less likely to be influenced by a desire to exploit the relational values in its renewal decision.

\section{Savings Generated by the Buyer's Investments}

In this case, repeat savings are generated by investments in the relationship, made by the buyer, that are transferable to a repeat transaction witl the seller but not to another supplier. For example, the buyer may

52. It is, of course, quite likely that the value of the savings will vary from client to client, and that the seller will only be able to predict the average savings, rather than the exact savings for a particular relationship, at the time of initial bargaining.

53. Since we are considering the initial transaction between buyers and sellers, they cannot, by definition, have dealt previously.

54. Variations in credit-worthiness, for example, are likely among unsophisticated clients, and knowledge about the credit-worthiness of particular clients is of great value to suppliers. People, for example, vary greatly on how quickly and dependably they pay bills-information that is almost impossible to obtain without actual experience with the party involved.

55. See supra text aceompanying notes 31-32. The buyer's exact demands will depend upon whether he can identify himself as a repeater. 
have trained himself or his employees to use the seller's product, or made other adjustments to be compatible with the seller.

Again, unless the seller is a newcomer to her business, she will be aware at the mitial stage of such investments unless they are highly idiosyncratic to the buyer. Even idiosyncratic adjustments are likely to be known to her by the time the renewal stage is reached. And the buyer will know more about the investments required of him at the initial stage than he will know about the seller's investments.

The buyer, however, may be unaware at the initial stage that he must make non-transferable investments in his relationship with the seller. Or, he may undervalue the extent of the investment required. The buyer may not realize that his investment gives the seller an incentive to engage in opportunistic behavior at the stage of negotiating renewal terms. It is also possible that the product may not perform as expected, requiring the buyer to make unanticipated adjustments. ${ }^{56}$ This would not only compel him to adjust to the seller's product, but might also make him less willing to risk switching suppliers, thus making the seller's product more valuable to him at the time of renewal.

In this case, the buyer's investment gives the seller an incentive to engage in hold-up behavior at the renewal stage to increase prices for renewal. The buyer will feel pressure to renew rather than find a new supplier if he views himself as having invested in repeating with the seller. A sophisticated buyer may attempt to protect himself by contracting over the longer period (if he is certain that he will repeat, and is also willing to take the market risk), ${ }^{57}$ or by demanding a renewal option. $^{58}$ Buyers who are unaware of, or who underrate, the relational value are likely to be squeezed by opportunistic behavior unless the seller is constrained by market forces.

The seller will be so constrained if she cannot discriminate, at the time of the initial bargain, between sophisticated and unsophisticated buyers, and if the shopping behavior of the sophisticated buyers compels sellers to offer appropriate renewal terms to all. ${ }^{59}$ Then, all buyers will be offered renewal terms that protect them from opportunistic behavior. This protection is limited, however, because an unsophisticated buyer who is both unsure of his need for continuing services, and unaware of the investments required for his relationship with the seller, may refuse the renewal term and open himself to opportunistic behavior. In short,

56. Here again, the seller is in a better position to know, if she has dealt in the contract good or service for some time, that some buyers (although not necessarily this buyer) will face such problems.

57. See supra text accompanying notes 33-37.

58. The current problems of writing enforceable renewal options are discussed infra text accompanying notes 76-80.

59. See Schwartz \& Wilde, supra note 42 , at $1402-06$. 
the renewal term itself may act as the screening device to separate sophisticated from unsophisticated buyers.

\section{Implications for Policing}

The previous two Sections demonstrate that the occurrence of relational opportunism in repeat transactions depends on whether repeat savings are generated by buyers or sellers, and on the nature and visibility of the investments generatimg the savings. Thus the choice of legal regime to govern repeat transactions also depends on the nature of the savings and the parties to the transaction. The likehihood of opportunistic behavior increases, and the ability of the parties to protect themselves by the initial bargain decreases as the parties' awareness of relational investments at the initial stage decreases. Consequently, sophisticated parties need less legal protection than neophytes who deal in similar transactions. $^{60}$ Further, less protection is necessary if the sophisticated players protect their less informed cohorts, or if the nature of the investment itself is obvious at the initial bargain. These themes will be elaborated further when legal regimes for repeat transactions are considered in Part III.

\section{Summary: Problems of Negotiating Subsequent Contracts}

While contract law assumes contractual relationships endure only for the duration of the contract term, relational values often do survive the termination of a contract. Where such values survive, both the parties involved and society benefit by continuing the relationship through a second or other succeeding contract rather than seeking a new source for the same services.

However, continuing relational values, coupled with the fiction of contract termination, lead to negotiating strategies that can cause socially unproductive behavior. These strategies may cause parties to waste resources in opportunistic hold-up negotiations. To the extent that these strategies result in decisions to terminate relationships and move to alternate buyers or suppliers, relational values are lost. While both parties may understand that they would be better off agreeing, short-term strategic or irrational behavior could result in the termination of socially worthwhile relationships. ${ }^{61}$ Further, where parties dedicate a portion of the relational values to lower prices on initial contracts, overestimating

60. In our example, the seller is less likely to need protection from a contract rule over her investments than the buyer is over his investments, since the seller is likely to be aware of her vulnerability in time to protect herself.

61. For example, a party might decide to accept the loss of a sunk investment on one contract by not renewing in order to send a message to future repeaters that it cannot be "pushed around." While this would be rational since that party might increase its take over many contracts, it would be 
the number of repeat transactions results in poor pricing decisions, generating losses.

Several factors determine whether and to what extent these problems will affect renewal negotiations. These factors depend on the - type of transaction under consideration and on the nature of the parties involved. For example, the ainount or importance of the relational values is significant. If very sinall anounts are at stake, any individual buyer is less likely to know or care to negotiate about relational savings. Sellers are less hikely to find it worth the cost to individualize transactions and provide incentives for repeating. In such cases, renewal savings are likely to be reflected in the price for all transactions. ${ }^{62}$

Further, the availability of information is of particular significance. Knowledge of the existence and amount of the relational values, and of the identity of repeaters, crucially determines the parameters of repeat transactions. Both the extent and timing of the information available has a significant bearing on ahnost every aspect of the problems of repeat transactions, including the number of repeat relationships (and hence the extent of savings); the extent (and hence the cost) of hold-up behavior; and the final distribution of relational savings.

Renegotiation problems may also be reduced by strategic decisions by the parties themselves. For example, if the parties anticipate a longterm relationship, promising greater rewards than short-term opportunism in renewal bargaining, they will not act opportunistically in the short term. ${ }^{63}$ Similarly, parties face reputational constraints on opportunistic behavior to the extent that future partners are likely to hear about prior opportunistic behavior. ${ }^{64}$

III

\section{Dealing With the Problem}

As currently constituted, contract law does not recognize the carryover of values in contracts between the same parties. ${ }^{65}$ There are good

socially wasteful because more repeat contracts would be turned down. One party, in short, has maximized its return at the cost of joint, and social gain.

"Irrational" behavior results where one party becomes annoyed with the strategic behavior of its partner and decides to terminate the relationship even if it is still economically beneficial.

62. Such savings could, in the aggregate, be quite considerable. Unfortunately, the cost of discriminating between repeat and initial transactions would still outweigh any savings.

63. Obviously, this constraint will not operate if they foresee a termination of the relationship. See R. Luce \& H. Raiffa, Games and Decisions 98-101 (1957).

64. See Scott, supra note 3, at 2031-34.

65. In fact, this ideology is so persistent that contract law will often fail to enforce clauses in the parties' first contract that require the parties to negotiate and renew their relationship at the termination of the existing contract. Unless the renewal terms are quite specific, courts will refuse enforcement of such terms on the ground that they constitute an illusory and unenforceable "agreement to agree." See infra text accompanying notes 70-73. 
reasons for this cautionary strategy. It may be very hard to identify and quantify these values. To recognize such values, and to bestow enforceable rights to uphold them, may only open the door to more and greater opportunism. It is this fear which has led some commentators, who have recognized the potential for opportumism inherent in relational values, to suggest that the parties are better left to their own devices. They argue that parties will devise strategies of cooperation, bonding, and reputational constramts on their own im order to minimize opportunism. These commentators, however, have focused quite explicitly on a narrow, but important, subset of all contractimg parties: sophisticated parties witl predictable, long-term relationships. ${ }^{66}$

Unfortunately, the relational problems of termmation are not limited to such sophisticated parties. Parties who lack the information or ability to negotiate or to monitor opportunistic behavior cannot protect themselves as can their more able cohorts. Moreover, to the extent that opportunism decreases the number of beneficial repeat transactions ${ }^{67}$ or increases the costs of negotiation, it decreases the social benefit from repeat savings. Thus, it would be worthwhile to devise strategies to enlance the likelihood that beneficial repeat transactions will in fact occur, while at the same time minimizing the scope for opportunism. In some cases, we miglit also find it fair to affect the distribution of the savings.

In this Part, I shall explore some possible avenues to encourage parties to continue their relationships. As I have suggested, the problems of relational opportunism affect not only the renewal of contracts, but also their performance. The ability to understand and control relational opportunism seems critical to our ability to give meaningful legal protection to contracts. ${ }^{68}$ I hope also to present some criteria that will identify

66. See, e.g., Scott, supra note 3 .

67. I have already suggested that the socially optimal number of repeat transactions cannot be assured when individual opportunistic behavior is at stake. Individual actors may maximize their gains by insisting on a greater share of each repeat transaction at the social cost of losing some repeaters. See supra text accompanying notes $41-44$ and note 61 .

68. Although meaningful contract enforcement must also police relational value opportunism during the contract, I have chosen to focus on repeat negotiations for two reasons. The first is the need to sensitize contracts scholars to the problem of relational values in contracts that are not termed "relational." We have for too long divided the world into "relational" and "non-relational" contracts on the basis of the predictability and size of contractual partnerships and have contented ourselves with the idea that such relational contracts can exist very comfortably without law. Yet relational values also drive those relationships that simply cannot engage in the forms of internal policing which are available to large-scale contractors. Once we decide that relational values are too important to ignore, we ought to devise better strategies to deal with them. Of course, we may discover that we cannot devise such strategies and that we had better leave contract law where it is. If so, we will at least be more sensitive to the limits of our ability to influence contract behavior.

Secondly-and this is a much more tentative suggestion-unless contracts actually result in breach, relational opportunism in modification will increase transaction and bargaining costs and affect the distribution of relational gains between the parties. However, such opportunism will not 
situations where opportunistic behavior is most likely. ${ }^{69}$

\section{A. Towards a Jurisprudence of Preserving Contractual Relationships}

Heretofore I have argued that renewal of contractual relationships can offer benefits, both to the parties involved and to society, which will be lost if the relationships are terminated. Nevertheless, negotiations of repeat transactions may generate significant friction as the parties jockey for advantage over the allocation of the benefits and may even result in fractured relationships.

At best, current contract jurisprudence ignores the existence of continumg values and the unique problems of opportunism in contract renewal, and often seems actively to discourage even the parties' own attempts to preserve the values and solve problems. Options to renew contractual relationships that do not specify the terms of the renewal contract with a fair amount of clarity often fail on the ground of uncertainty. ${ }^{70}$ This leaves parties who have the foresight at the time of initial contracting to think about renewal with the Hobson's choice of specifying terms that may prove to be inappropriate at the time of renewal or of including a good faith renewal term that runs the risk of unenforceability. It is therefore reasonable to conclude that, against this backdrop, parties with the requisite foresight and stake in the outcome will attempt to generate extra-legal methods for regulating their relationship. ${ }^{71}$ Some commentators have suggested, therefore, that legal attempts to police relational opportunism may only result in fouling up the parties' own systems for dealing with opportunistic behavior. ${ }^{72}$

There is good reason to be cautious about regulating repeat transactions and, hence, good reason for the contract system's reluctance to do

reduce relational savings. In contrast, where renewal is involved, contracts might not be renewed, with the social losses associated with such waste. I suspect (with nothing to back it up) that breach is much more effectively controlled by extra-legal means than is non-renewal. In a way, I am suggesting that the formal and moral status given promise is more likely to induce performanceeven if coupled with opportunistic attempts to alter the terms-than are informal, future implicit obligations to deal in good faith with contracting partners.

This, to me, is a further argument for recognizing a legal obligation to continue to deal in good faith about relational values that survive contract termination. To the extent that legal rules influence the norms of expected conduct, legal renewal obligations may themselves lead contracting parties to consider such conduct a part of the normal background of "good faith" dealing.

69. I shall not consider here the cases in which we might wish to affect the distribution of the repeat savings between the parties. Distributional considerations that warrant public scrutiny are a major topic in themselves and raise issues across a broad spectrum of contract concerns. They are therefore better considered in articles dedicated to only those issues. See, e.g., Singer, supra note 44. The suggestions presented here, then, are not meant to be considered as a complete system of policing contract termination. They are, rather, to be supplemented or modified by rules that address such important factors as unconscionability or disparity of bargaining power.

70. See infra text accompanying notes 76-80.

71. See, e.g., Scott, supra note 3, at 2039-40.

72. See, e.g., id. at 2044-46. 
so. It will often be difficult to identify, and especially to quantify, relational values that warrant protection under the rubric of renewal rights. If we rely upon the parties for this function, there is the danger that one of them will be tempted to misrepresent the advantages in order to exploit the other, especially where we depend for enforcement upon a costly legal process. In short, the very rules intended to facilitate savings gained by repeat transactions may themselves lead to opportunism. Moreover, a refusal to renew may reflect dissatisfaction with rendered services rather than an opportunistic attempt to appropriate relational savings. Recognizing a right of renewal would force the dissatisfied party to justify its decisions, thus raising the cost of enforcing quality. ${ }^{73}$

Perhaps most troubling ideologically is the possibility that by regulating repeat transactions we might force parties to stay in relationships that they do not want to continue. As a society, we have chosen on the whole not to not require specific parties to deal with each other, however socially or individually beneficial we may believe it to be. ${ }^{74}$ While we must be sensitive to the problems, however, we should consider possible strategies to identify and encourage worthwhile repeat transactions while minimizing the harms that such rules may cause.

In this Section. I discuss the possible advantages and costs of three strategies, and the types of relationships for which they might work to the best advantage. First, I discuss the strategy of simply enforcing renewal clauses already mcluded in imitial contracts. The existence of a renewal term would suggest that the parties have identified a relational value worth preserving, adjusted their price accordingly, and taken the risk of costly negotiations and enforcement of the renewal term. Thus, the parties have themselves indicated that they believe relational values exist that are worth the cost of enforcement. To the extent that sophisticated parties prefer private enforcement systems, they may signal a "hands-off" to the courts by not including such a term. This limited strategy, however, does little to solve the problems of less sophisticated parties or prevent the social wastes generated by smaller dealers who may collectively generate significant efficiencies by renewing, yet fail to focus initial negotiations on the problem because they individually have insufficient stakes in renewal.

73. In addition, the possibility of enforced repeating might deter parties from initiating relationships, or equivalently increase costs as perfectly informed parties and markets reflect the cost of the rule of enforced repeating in the price structure of the initial contract. Similar problems are encountered in debates about whether to enforce termination-at-will clauses.

74. This is reflected in the fear of "paternalism," which, as witnessed by fair-housing statutes, is by no means absolute. It is fair to say, however, that such forced association is considered ideologically suspect and is used sparingly-and usually by legislative fiat. Examples of judicially created forced relationships do exist, however, such as the law of easements. See generally Singer, supra note 44 , at $663-78$. 
Second, I consider the possible consequences of creating a presumption of renewal for contracts. This presumption may be rebutted by explicit terms in the contract. It is thus an off-the-rack term which parties may elect to reject if they have the requisite information about the law. It would, however, invert the current presumption of concurrent termination of contractual values and contracts. It would also amount to a mandatory term in the cases where parties lack the sophistication or the incentive to negotiate over continuing values at the initial stage. ${ }^{75}$

Finally, I shall examme the possibility of a mandatory (that is, a noopt-out) requirement of "good faith" negotiation for renewal terms. This approach would diverge from imposing a presumption of renewal only for sophisticated parties who would have sufficient information about their relationship and the law and choose to opt out of renewal obligations. I shall suggest that such a mandatory term directed to sophisticated parties may be appropriate in some situations.

In discussing these possibilities, it becomes apparent that the best strategies may well depend upon the type of contractual relationships at issue. I therefore conclude by suggestimg that a mixed strategy might provide the most fertile area for further consideration.

\section{Current Approaches: Enforceable Renewal Clauses and Unenforceable Agreements to Agree}

Currently, contract law recognizes no obligations extending beyond those actually specified in a contract. Any renewal obligation, therefore, must be explicitly set forth in the initial contract. But even explicit contractual undertakings to renew may fail to be legally enforceable if they do not adequately set forth the terms and conditions of the renewal contract. Renewal clauses that lack the required specificity run the risk of being considered "agreements to agree" rather than agreements. Courts may conclude, where parties leave terms to future negotiation, that they have not manifested an intention to be bound if they later fail to agree on the open terms. ${ }^{76}$ Moreover, even where such clauses are not considered per se unenforceable, the same result may follow if courts decide that the agreement provides insufficient information to fashion a remedy. ${ }^{77}$

75. I am using, as a useful construct, the inception of the initial contract as the "initial stage." Often, however, important relational values build up over the time the initial deal is negotiated. See Farnsworth, supra note 7. Since much of the argument here is independent of how the existing relationship was created, I have simplified matters by treating the "initial" deal as non-problematic in this sense.

76. See, e.g., Ridgway v. Wharton, 10 Eng. Rep. 1287, 1297-99 (H.L.1857).

77. See, e.g., Ablett v. Clauson, 43 Cal. 2d 280, 286, 272 P.2d 753 (1954) ("The only term fixed by the option provision as contemplated by a new lease is its duration. All of the other provisions are left to future agreement. In these circumstances, the terms of the option are too uncertain to make it enforceable as a contract right"). 
Where terms are uncertain, courts fear that they will impose a bargain on the parties.

Dissatisfaction with the current approach to repeat contracting centers on failures to enforce renewal clauses because they are uncertain, and there are signs that the law is changing in this area. ${ }^{78}$ It is still by and large true, however, that courts and coininentators alike are satisfied that the parties themselves inust intend, at the time of the imitial contract, to be bound in a repeat contract whether or not they are able to reach agreement subsequently on the terms of the renewal. ${ }^{79}$ Thus, it is crucial to determine whether the parties intended to terminate the relationship if they subsequently failed to agree on open terms, or whether they intended to continue their relationship with terms supplied by other 1neans. Simce exphicit expressions of intent on this poimt during contract negotiations are rare, courts inust often look to other evidence, such as the parties' expectations that one of them inust rely on the continuation of the relationship, for gnidance in resolving this issue. ${ }^{80}$

\section{a. Option One: Enforce Renewal Clauses}

The simplest strategy to deal with contract renewal-and the one least disruptive of current practice and ideology-is to continue to require that parties identify renewal rights in their initial contracts, but to enforce renewal clauses where they exist. Terms upon which parties fail to agree could be supplied by the court. The knowledge that the renewal right will be enforced-if necessary, on terms deemed fair by a court-will in itself encourage the parties to reach agreement. There is little doubt that the legal right of enforcement will change the bargaining positions of the parties, strengthening the hand of the person who will profit by continuing the relationship while weakening that of the one who will benefit by termination.

Where the parties have included a renewal term in their initial contract, neither doubt as to their intentions in the event that they fail to agree nor a fear of judicially inposed redistribution justifies treating a

78. Such change is most noticeable in the sales of goods. U.C.C. § 2-305 permits parties who intend to be bound to make sales contracts with open price terms. In the absence of agreement, the price terms are supplied by the UCC itself. This liberalization is due in part to the presumption that a market term may be supplied for the missing terms and that market terms represent the most likely choice of the parties. E. FARNSwORTH, supra note $8, \S 3.28$, at 197. As I have suggested, this may ignore the possibility that relational savings may be achieved which may not be refiected in the market price. See supra text accompanying note 7. Thus, the use of the market price may be more distributional than supposed in that it allocates the entire savings to one party or the other.

79. E. FARNSwORTH, supra note $8, \S 3.28$.

80. Note that while reliance is usually considered for its value as evidence of a party's intent, a focus on reliance would also help in minimizing problems of opportunism. Reliance is evidence of investments made by a party in the relationship and, hence, evidence of the existence of "appropriable quasi rents" that yield the potential for exploitation by the other party. 
renewal term as if it has no legal significance whatever. If the parties initially invested their resources to include such a term, they must have suspected that the relationship would generate continuing values that they might want to exploit, or they feared that one of them might use such values opportunistically. In short, this is a case where the parties themselves have identified repeat values that are worth the costs of enforcing repeat obligations.

Moreover, if the parties believe that the term creates legal rights, treating the renewal clause as if it has no effect is just as redistributive as imposing a term in the absence of agreement. What the parties agreed to-what they bought and paid for-has been changed by the court, whether by refusing to enforce a right the parties believed that they had created or by supplying a term different to the one the parties would have chosen. ${ }^{81}$

As previously discussed, courts enforce renewal clauses if they satisfy one of two conditions. Renewal clauses are enforced if they provide reasonably definite terms. They may also be enforced if the parties demonstrate an intent to be bound in the event of a failure to agree on open renewal terms. The latter reason, that parties may not have intended that they should be bound unless they could agree, is ideologically more significant than the former, a concern over indefiniteness. Requiring party intent goes to the very heart of requiring that contractual duties be self-imposed and consensual. Taking this requirement of consent as a given for the present, ${ }^{82}$ must it lead to the current doctrinal position that renewal terms are given no effect unless it is clear that the parties intended open terms to be supplemented externally? Put differently, why might parties have open renewal terms, and what effect might they expect such terms to have? Is it more likely that they intend to create some binding obligation than none? If they do intend to create some obligation, what is it likely to be?

It is highly unlikely that parties would include a term for renewal upon terms to be determined later which creates no obligations or rights whatever. It is, of course, possible that the parties intend no legal consequences. Parties are likely to want a right of renewal to the extent that they fear, at the time of initial contracting, that the contractual relationship will generate relational values that will create incentives for oppor-

81. Of course, if the parties have perfect information, any decision by the court is not redistributive. If we do not enforce the clause, the parties-knowing this-do not include the cost of the clause, except insofar as they can enforce it extra-legally. If we do enforce it, the parties include the cost of enforcement. In the latter case, we simply deprive the parties of the choice of a legally unenforceable renewal option with open terms.

82. I later challenge this premise, at least for some types of contracts. See infra text accompanying notes $115-25$. 
tunistic behavior at the renewal stage. ${ }^{83}$ Uncertainties about the future, however, will often make the parties reluctant to set the terms of future dealings-especially where contracts are interpreted legally as allocations of risk. After all, as the parties' certainty about the future increases, or as they become more willing to assume risks, they can plan for longterm, rather than repeat, contracting. In addition, parties may feel uncertain, for example, about the quality of service that they will receive. They may prefer to keep the option of terminating the relationship later, either to provide incentives for quality or to allow termination when they are better informed about the nature and quality of contractual services.

This would suggest, therefore, that open-termed renewal clauses might be chosen as the best option for balancing several objectives. They could minimize relational opportunism by imposing an obligation to repeat while they reduce other risks by allowing parties to set terms appropriate to the conditions at the time of repeating. They could also mimimize incentives to shade quality by allowing parties to back out of the repeat obligation if quality is unsatisfactory.

Parties do intend to inpose obligations through renewal clauses to bargain so as to reach agreement. To find no obligation guts the objective of the clause insofar as it is meant to deter opportumsm created by relational values. Parties must intend at least an obligation to negotiate in good faith ${ }^{84}$ to reach agreement on the terms of the repeat contract. Thus, parties must negotiate to reach agreement on the terms of the next contract, negotiations in which they do not engage in opportunistic attempts to appropriate relational values, although they may need to adjust contract terms to respond to conditions at the time of renewal. At the same time, the parties would allow a failure to renew for "good cause"-for example, because they no longer need the service or because the quality of the service is unsatisfactory.

It would therefore make sense, even under the consent model of enforcement, to interpret any repeat clause as imposing a good faith obligation to bargain to agreement on repeat contracts. An unexcused failure to reach agreement should allow the court to impose agreement on "reasonable" terms. ${ }^{85}$ Courts should be particularly sensitive to the need

83. See supra text accompanying notes 31-37.

84. It is very hard to find a good interpretation of what constitutes "good faith" negotiations that focuses on substance rather than on procedure. See, e.g., Farnsworth, supra note 7, at 269-73. While requiring a minimal procedure will imposé some limit on opportunistic behavior because these minimum procedures will expose opportunistic parties to increased costs, some substantive measure is necessary to truly deter opportunism. I suggest here that we at least try to identify situations where opportunism is most likely, and in those situations be willing to impose terms to enforce repeating. While this may well have distributive effects, we do ensure the continuation of the relationship, and hence achieve the socially beneficial savings associated with repeating.

85. The knowledge that the court will enforce the repeat contract on terms of its choosing will itself change the dynamics of the parties' negotiations, as opportunistic threats to end the 
to enforce agreements to repeat where the relationship is likely to have generated exploitable dependencies or investments. The parties should then be able to counter the obligation by showing that they no longer need the contracted-for services ${ }^{86}$ or that the services failed to reach an expected standard of quality. ${ }^{87}$

This regime would enforce repeat contracts only where the parties themselves mitially recognize the possible values of repeating and determine that the value exceeds the costs of negotiating and enforcing a repeat clause. ${ }^{88}$ Moreover, it would leave the parties free to conclude that even where relational repeat values will be created, they are better off pohicing opportunism in their own way. ${ }^{89}$ It would therefore allow parties with knowledge, foresight, and sufficiently large stakes in repeating, an additional option to deter relational opportunism and generate the social savings associated with repeat contracting. It would not, however, affect the situations where real savings might exist but the parties prefer to take the risks associated with possible opportunism of their partners in order to be in a position to make their own opportunistic attempts. Nor would it affect contracts between unsophisticated parties, or those in which repeat savings are small individually, but whose total might create significant social savings.

\section{b. Option Two: Impose an Implied Term of Renewability}

A second approach, which would have a greater effect on contracting than merely enforcing existing renewal terms, would be to imply a renewal term where contracts are silent as to renewal. This would allow parties to expressly exclude renewal rights; that is, it would allow parties to opt out of renewal obligations. Since this would simply invert the current presumption that parties do not intend to renew, it would be

relationship would be limited to the value of litigation costs. The threat of litigation, however, may also give the parties a potential for opportunism-for cxample, where the parties are aware that termination may be justified. Nonetheless, where thc parties themselves have chosen to include the repeat term, we may conclude that, on the whole, the costs associated with enforcing the clause will be less than those of not enforcing it.

86. For example, they could show that they have not bargained for, or received, similar services from someone else.

87. Obviously, there may be situations where parties might prefer to terminate services for poor performance without having an obligation to show cause. In such cases, the obligations imposed here might well be onerous. The situation is analogous to "termination-at-will" elauses. The debates surrounding such clauses would equally apply here, except that here such parties may protect themselves from a need to justify termination by not including renewal options. This would also serve to place parties on notice that problems of opportunism might well complicate renewal negotiations.

88. Thus the rule is "efficient" if we assume that parties are knowledgeable and will usually prefer not to have a repeat obligation.

89. This answers Professor Scott's fears of upsetting tit-for-tat strategies. See Scott, supra note 3 , at 2044-46. 
deemed an efficient, and hence presumptively appropriate, rule (in law and economics analysis) where the costs associated with bargaining out of renewal clauses are lower than negotiatimg them. ${ }^{90}$ Under this view, imposing an opt-out provision of renewal does little violence to the ideology of party autonomy. The choice between the two options is driven purely by comparisons of the costs of bargaining for and enforcing the two alternatives.

Nevertheless, inverting the current presumption of non-renewal will have significant effects either where parties are unsophisticated about their transaction or about the law and hence do not consider renewal at the time of the initial bargain, or where the costs of negotiating about renewal at the initial phase are prohibitive. Such contracts are currently deemed to not include renewal rights, but under an implied-term regime, they would be read to include such rights and the parties would be required to justify refusals to renew. The ideology of party autonomy is maintained, then, only by the fiction of assuming that parties either know, or should know, the rules of the game and all risks of contracting. ${ }^{91}$

In appraising the value of presuming renewal rights, then, we must consider the relative cost of opting in versus opting out for the sophisticated, and the relative cost of non-renewal versus renewal for the unsophisticated. ${ }^{92}$ Implying and enforcing a renewal clause would present all the problems discussed in Option One, with one additional problem. In this case, the parties themselves have not identified a value worth preserving. ${ }^{93}$ Courts will therefore have to determine if repeat values worth preserving exist. In practice, this would be necessary only in cases of unsophisticated bargainers, or where values at the initial stage are insufficient to merit attention by the parties. ${ }^{94}$ Sophisticated parties with repeat values great enough to justify their consideration at the initial contractimg stage may, if they choose, negotiate opt-out provisions which will be respected by the courts. If courts enforce repeat clauses where repeat values are insufficient, they will create a new source of oppor-

90. Such "costs" must include all relevant factors, including the likelihood and magnitude of repeat values, costs of negotiation, etc.

91. There is nothing new about invoking this fiction in order to preserve the fiction of party autonomy. It is prevalent in contract law. See, eg., Narasimhan, supra note 18, at 1174-75.

92. I do not mean to exclude other reasons to impose-or deny-renewal obligations. One might, for instance, wish to shift the relative power of the parties, or protect parties that are likely to rely on the possibility of long-term relationships. See infra notes 115-118 and accompanying text.

93. I am speaking here of parties that may not be fully informed and sophisticated with respect to the possibility of repeating at the initial stage. If they are, of course, they will opt out unless the costs of doing so are prohibitive.

94. I would again stress that repeat values can be insufficient to trigger negotiations at the initial stage not simply because they may be small in a given case, but also because of the uncertainty that any given player will repeat. 
tunism where parties can engage in hold-up behavior before allowing their partners to terminate the relationship. ${ }^{95}$

It is perfectly plausible that the opt-in strategy might be more efficient for some kinds of sophisticated planners, ${ }^{96}$ while real savings might be achieved by encouraging repeat transactions in other types of relationships. Thus, a mixed strategy adopting different approaches depending upon the nature of the transaction and the parties would be the most promising. ${ }^{97}$ We could maintain a two-tiered system under which a determination that parties are sophisticated would invoke a presumption of non-renewabihty (that is, retain the status quo) if in fact most sophisticated parties would prefer non-renewal, ${ }^{98}$ and a determination that parties are unsophisticated would put them into a regime of presumed renewability. We would then allow sophisticated parties to plan renewal and self-policing strategies at the inception of their relationship when renewal opportunism is at its minimum, ${ }^{99}$ but provide legal rules as a background for negotiations in cases where parties are unlikely to invest in such planning until renewal time-the point of maximum opportunistic potential ${ }^{100}$ _arrives.

It is, of course, extremely unlikely that repeat players will remain unsophisticated about the problems of renewal. Thus, parties in the business of selling a particular product are likely to be sophisticated about negotiating repeat transactions. It is quite possible, however, that their buyers will not be as well informed. In such cases, market conditions might force sellers to compete by using repeat savings to reduce prices for initial sales at the risk of losing repeat customers, thus forcing sellers to walk a tight-rope. ${ }^{101}$ A strategy that would enforce renewal clauses and also confer a right to repeat where contracts are silent as to renewal might well shift the bargaining dynamics such that sellers could either insist on allocating repeat values to repeat contracts (perhaps by auto-

95. Parties could use the threat of litigation over repeating to make their partners buy the right to terminate. Imposing repeat obligations cannot be economically justified, then, unless the value of repeating exceeds the costs of litigation over repeating, considering such factors as the difficulty of proof and the likelihood of error.

96. Such might be the case, for example, in long-term relationships of great value where the parties rely on extra-legal policing strategies, and where they fear the disruption of their own strategies-by court action, as suggested in Scott, supra note 3, at 2039-46.

97. The costs of litigating and enforcing the rules must obviously be considered in devising any strategy.

98. Notice, however, that in this alternative, small value cases would again escape renewal obligations, unless a demonstration that small repeat values are involved is allowed to defeat the presumption of non-renewability.

99. See supra text accompanying notes 34-38. Notice the distributional consequences of this option; sellers will, on the whole, be forced to allocate renewal surpluses to buyers.

100. See supra text accompanying notes 34-38.

101. In reducing their prices for initial sales, sellers may fail to maintain adequate incentives to keep all potential repeaters. See supra text accompanying note 32. 
matically including a repeat term im initial contracts), ${ }^{102}$ or enforce repeat contracts even where the initial allocation was made to all contracts. Either reaction would reduce the social loss attributable to repeat losses and deficit financing losses, although their distributional consequences are quite different. ${ }^{103}$

To the extent that buyers remain unaware of the repeat savings, ${ }^{104}$ sellers will have to police the repeat transactions. Then, if the sellers see an advantage $\mathrm{m}$ maintaining a situation in which repeat savings are allocated to induce initial sales, ${ }^{105}$ inverting the current presumption of nonrenewability will have little effect.

\section{c. Option Three: Impose a Compulsory, No Opt-Out, Renewal Term}

A third possibility would be to impose a compulsory renewal term. Then, unlike the previous regimes, parties would be unable, even if they consider the matter at the initial negotiation, to choose a no-renewal contract strategy. They would then be required to renew, unless they could justify such a non-renewal-for example, by slowing the lack of need for the preferred goods, a failure in the expected quality, or tlie lack of repeat values. This regime would do the most violence to the ideology of party autonomy, although in practice it would differ from that of a presumed renewal term regime only for the sophisticated bargainer.

Putting aside, for the time being, the thorny issue of autonomy, analysis of the compulsory term must focus mainly on its effect on sophisticated parties. Unsoplisticated parties were largely defined as such because of their failure to consider repeating strategies at the initial negotiations. Thus, the effect of a compulsory term is much the same as the effect of the opt-out presumption of renewal analyzed in the previous section. Whatever the technical form of the rule, parties who do not consider repeating strategies at the inception of the contractual relationship $^{106}$ will be expected to justify a failure to repeat.

102. As renewal clauses would be enforceable, both parties would be more willing to postpone collecting their renewal gains to the renewal stage, since they would be less vulnerable to exploitation of sunk investments made in anticipation of the renewal savings. See supra text accompanying notes 37-39. This is, of course, limited by the possibility of using litigation threats for opportunistic attempts.

103. In the first case, repeat buyers would claim the lion's share of the proceeds; in the second, all buyers would see a reduction in price. See supra text accompanying notes 34-38.

104. This might be the case if savings consisted solely of efficiencies to a seller in delivering the contract goods or services. See supra text accompanying notes 52-55.

Of course, it is sufficient that buyers (or rather a sufficient number of buyers to police seller behavior, see Schwartz \& Wilde, supra note 42) become aware of repeat values at the point of renewal. In fact, if buyers become aware of the values, it is sellers who will be at risk of buyer opportunism, and this ean cause losses of repeat values. See supra text accompanying notes 52-55.

105. See supra text accompanying notes 41-44.

106. Although I am focusing on the "unsophisticated," this applies equally to those who, rightly 
This regime, however, is the only one that will force sophisticated bargainers either to repeat or to justify not doing so. Sophisticated bargainers will not, therefore, be able to self-identify situations where the relationships generated during the initial contract are not sufficiently valuable to warrant continuing the relationship through repeat contracts, or where enforcement costs of repeat transactions are excessive. Such a regime could be cost-justified in at least two situations. First, a coinpulsory repeat obligation inight be justified in situations where repeating would generate significant savings, but individual contractors would prefer to postpone negotiations over repeat contracts to the time of repeating in order to exploit the opportunistic possibilities. In such situations, the social value of repeating is sacrificed to private opportunism. ${ }^{107}$ Second, a compulsory repeat term regine might be appropriate in situations where the private, ex ante evaluations of the parties-which, after all, are based upon incomplete information ${ }^{108}$ - of either the values generated by repeating or the relative cost of private and public enforcement strategies are unlikely to be as accurate as public, ex post evaluations.

In evaluating this alternative for sophisticated parties, we inust consider the effect of a compulsory ex post renewal requirement on initial negotiations. As the option of deferring negotiations over renewal without any commitment to renew would no longer be available, ${ }^{109}$ the parties would appear to be linited to only three choices: a renewal term; no renewal term, with the likelihood of future opportunistic negotiations over renewal terms; or a long-term contract, with its problems of risk allocation. Will this lead to increased offers of renewal terms, rather than an allocation of repeat values over all initial contracts? ${ }^{110}$ Will parties who feel some degree of certainty of continuing need for the services be driven to long-term contracts with the attendant costs of complete risk

or wrongly, find consideration of repeating strategies at the initial negotiation not to be worth the cost.

107. See supra text accompanying notes 32-36. In this discussion, I have not examined another probable way in which a no opt-out renewal obligation might decrease problems of renewal opportunism. To the extent that parties do act in good faith, and if legal rules help to define parties' background expectations of acceptable conduct, a presumption that renewal is required may help to create an ethic of good faith conduct over renewal negotiations. See supra text accompanying notes 84-85.

108. They are projections into the future of the value of repeating and of the eflicacy of private game-playing strategies. 89.

109. Unless, of course, they can invoke any defenses such as the ones suggested supra notes 86-

110. I have suggested that risk-averse buyers will prefer to see savings up front, driving sellers to use repeat values to reduce prices on all initial contracts while saving a fraction of the value to induce the repeat sale, thus resulting in a risky form of deficit financing. See supra text accompanying notes $39-40$. A rule requiring repeat transactions will strengthen a seller's hand in that buyers will now be unable to threaten to leave the seller at the repeat phase without good cause. This may well reduce the value, in buyers' eyes, of an initial allocation of repeat values to all buyers, rather than just to the repeaters. 
allocations? ${ }^{111}$

A compulsory renewal regime could also, if applied to contracts with insufficient repeat value, create a potential for opportunistic threats to litigate failures to renew. Such threats are more likely to come from sellers. ${ }^{112}$ However, it would seem hikely that, especially when deahing with sophisticated parties, reputational constraints would place limits on the extent to which sellers can engage in such behavior. ${ }^{113}$

In addition, to the extent that parties prefer to rely on private enforcement strategies to generate contractual harmony, requiring renewal obligations would remove a potentially powerful weapon from the private arsenal. Sophisticated planners would be compelled, in cases where they foresee the possibility of a long-term need for the services under consideration, either to negotiate long-term contracts or to put off the negotiations over renewal until the renewal period-but with the knowledge that failures to agree will result in an external imposition of the terms of the repeat contract. Threats to termmate the relationshipespecially where non-cooperation falls short of "good cause" for failure to renew-would no longer be available for private policing of the relationship. ${ }^{114}$

The suggested analysis has, so far, focused upon the balance of econonic benefits and costs of mandating renewal clauses. Even if significant benefits would accrue from imposing such a regime in some cases, however, the suggested scheme is susceptible to attack upon ideological grounds. Imposition of a term to force some parties into deals they do not want to make appears to be a powerful and particularly inappropriate intrusion on party autonomy. ${ }^{115}$ But incursions on party autonomy are made, often covertly by invoking fictions to deduce imaginary con-

111. See supra text accompanying notes 34-38 for a discussion of the costs of attempting to write long-term contracts to the extent that the legal system interprets them as allocations of risk.

112. Although relational problems might occasionally induce sellers to prefer to stop dealing with particular buyers, opportunistic threats by buyers to litigate non-renewal would appear, on the whole, to be problematic because sellers would usually be perfectly willing to renew. The price of renewal, of course, would be subject to friction. Sellers, on the other hand, would be able to threaten unwilling buyers, because not all buyers would want to renew, or because some buyers would have bona fide reasons to switch sellers.

113. It is, of course, true that similar constraints might (and often will) operate to control other forms of seller opportunism. I suggest, however, that a reputation for making threats to litigate in order to force unwilling buyers to renew, or to buy themselves out of renewal, would be far more damaging than a reputation for robust bargaining on the price of non-mandated renewal contracts.

114. Professor Scott's analysis suggests that such cases would be the norm, as the private strategies are aimed not so much at ensuring performance as explicitly agreed to in the contract, but rather to enforce inchoate cooperation strategies to modify and change obligations to adapt to ongoing needs. It is unlikely that such failures to cooperate could be adequately determined by good cause adjudications. See supra note 3.

115. Contracts are viewed as the paradigmatic case of "consensual," self-imposed obligations, and thus peculiarly the province of individual autonomy. See generally C. FRIED, ConTRACT AS Promise (1981). Hence, it is considered particularly inappropriate and "paternalistic" for courts to 
sent, ${ }^{116}$ and sometimes explicitly to correct perceived social problems in the contracting process. ${ }^{117}$ Although the suggestion that parties be forced to renew may appear more extreme ${ }^{118}$ than simply adding a clause to an existing undertaking, I believe that many of the arguments that support party autonomy lose much of their force in the renewal context.

Consider, first, the economic reasons supporting the norm of autonomy in contract. In general, a voluntary exchange between two completely informed parties is presumed to enhance value to both: If either party does not see an increase in value by agreeing to the exchange, she will not engage in the transaction. Thus, voluntary exchanges, by presumption, will increase the net wealth of the parties since each now values what she has received more highly than what she traded away. Moreover, if the transaction creates no external effects, the net social welfare will have increased because the parties are better off as a result of the transaction while none has suffered.

This view often implicitly underlies many of the arguments used to support noninterference in private dealing. It loses much of its validity, however, if party autonomy results in a net loss. This can occur, for example, if parties are poorly informed or, as I have argued here, opportunistic. In the repeating context, party autonomy would be used to support rules that allow private parties to bicker over the distribution of profit at the risk of losing socially beneficial exchanges. Nor does this increase of party autonomy benefit the parties themselves, since transactions which are mutually beneficial may not occur as a result of individual game playing and risk taking. When transactions do occur, their value may be much reduced by the transaction costs of negotiating the repeat obligation. Moreover, the rules that generate the potential for wasteful opportunism are artificial boundaries created by the legal system itself.

Mote troublesome are the humanistic reasons for allowing parties the freedom to choose their partners. I see these reasons as representing

\footnotetext{
"write their own concept of what would constitute a proper [agreement]." Walker v. Keith, 382 S.W.2d 198, 204 (Ky. 1964).

116. For example, parties are presumed to have foreseen all risks and to consent to all applicable law, however bizarre. See Narasimhan, supra note 18, at 1180-82.

117. Such "incursions" may be made by judges, such as the doctrine of unconscionability or the reading-in of warranty clauses, or by legislation, such as in rent control statutes.

I stress that although I have focused here upon economic arguments for or against rcnewal rights, I do not mean to suggest that these are the only, or even the most important, considerations. Other social goals, such as reallocating bargaining power, protecting reliance interests, or protecting a way of life, might well support renewal obligations. See, e.g., Singer, supra note 44 (arguing that the law should impose obligations on companies engaged in plant closings).

118. Insisting upon renewal obligations is in fact not unprecedented if we consider legislative attempts to coordinate the private gain in contracting with broader social gains. Rent control, for example, typically requires some form of renewal obligation.
} 
two different, yet related, types of concerns. First, the freedom to choose contracting partners allows parties to cater to private tastes and preferences within their environment. ${ }^{19}$ The second set of reasons centers on notions of empowerment; it is empowering to believe that we have some control over how we live. ${ }^{120}$ This sense of power may be purely illusory, but it is necessary to a sense of dignity. ${ }^{121}$ Thus, choices about the work we do, where we live and with whom, and how we spend our time and earnings are precious to us, and these choices contribute to our sense of ourselves as "free."

These concerns cannot be equally valid for all types of contracts between all parties. The importance of the ability to cater to private tastes, to personal likes and dislikes, must depend upon the extent to which the particular relationship requires close cooperation and contact. Similarly, our sense of empowerment must depend upon the importance of the relationship and upon the extent to which enforced associations of that nature threaten the core of self-identity. For example, a contract that requires a party to accept a weekly order for, and subsequently deliver, a fungible good would occasion less concern than one that required the party to work continually under the direct supervision of her partner.

119. This type of concern underlies contract law's reluctance to grant specific performance for breaches of personal service contracts. See, e.g., Fitzpatrick v. Michael, 177 Md. 248, 254-59, 9 A.2d 639, 641-43 (1939).

The most obvious example is that of marriage. Although the practice of arranging marriages does exist even within this culture, Hartman, Arranged Marriages Live On, N.Y. Times, Aug. 10, 1988, at C12, col. 4 (city ed.), a large majority of Westerners would be uncomfortable with a system other than direct personal choice for such a pervasive and intimate relationship.

120. Although this reason is related to the first one concerning personal taste, it is not the same. Consider, for example, a case where one's parents have in fact chosen a partner to one's taste. One will be happy with one's parents' choice, but one will not feel empowered.

121. Take, for example, someone who must work for her living and is tied financially or emotionally to a town where there is only one employer who offers work at her skill level. This person is in large part trapped and cannot choose her work environment. Yet few of us would doubt that she would resent being ordered to work for that employer by the government.

I do not mean to glorify this illusory sense of empowerment or to imply that it should stop us from making changes that will result in true increases in power for such cases. Such an approach would simply duplicate the free will apologies for retaining the status quo seen in many labor contract decisions of the past. See, e.g., Farwell v. The Boston \& W.R.R. Corp., 45 Mass. (4 Met.) 49 (1842) (master not liable for negligence of one servant to another unless expressly specified in employment contract). It would also continue the highly problematic ideology of consent divorced from the constraints imposed by the power hierarchies under which the consent is given. See, e.g., MacKinnon, Feminism, Marxism, Method, and the State: Toward Feminist Jurisprudence, 8 SiGNS $635,646-55$ (1983) (describing the illusory line between "rape" and "consensual sex" where female "consent" is given in a regime of male dominance).

Nonetheless, I do believe that (at least in this society) human beings need some sense of power and control over their lives, especially if they are to find the strength to change them. We must not reduce the little confidence they have without good reason.

Compare a slave who is given the best of everything to the worker described above. How many of us would prefer to be the slave? 
Moreover, in the case of repeat contracting, the parties are being asked to work with partners they initially chose and with whom they once felt able to work. Our fear of enforced relationships, then, should be limited to the few that we chose for ourselves at some past time. I do not suggest that relationships might not deteriorate to the extent that it would be distasteful to enforce continuation. I simply suggest that we should consider the possibility that parties who are capable of continuing the relationship-either because it does not require a great deal of interaction or because it has not become irretrievably sour-should be given incentives to do so where the advantages of doing so are great. ${ }^{122}$

More importantly, a party is not a party is not a party. The need to give vent to individual tastes and to experience a sense of personal empowerment is not relevant to all contracting parties. Such psychic and psychological needs presuppose a sentient entity and are, therefore, of importance to people who engage in relationships. These concerns have little reason to exist where the contractors are impersonal entities. Most corporate actors are usually deemed, and expected, to act in their best economic interests. They are usually not expected, or encouraged, to act in economically detrimental ways in order to express their individuality. Occasionally, contract law does explicitly distinguish between the individual and the business contractor. ${ }^{123}$ I suggest that this sensitivity to the character of parties be expanded. Whenever concerns of party choice or autonomy are at issue, for example, analysis should diverge along two branches. For the purely business relationship, the efficiency rationale for autonomy should be determinative in decisions on whether to override party autonomy. In contracts where more personal factors can come into play, the problems of taste and power must be considered and may become determinative. ${ }^{124}$

122. Oddly, the areas where these conditions are least likely to be fulfilled are the ones where we appear to be most willing to require that relationships continue. Divorce laws have often been much less generous than mainstream contract laws to the need for exit from unpleasant, intrusive, and disempowering relationships. See, e.g., Washburn v. Washburn, 9 Cal. 475 (1858), (wife denied divorce on alleged grounds of nonsupport; although husband was unemployed and not actually contributing to wife's support, wife's income was imputed to her husband). Similarly, at least some scholars suggest that parties be allowed to negotiate enforceable agreements that make exit from marriage difficult. See Scott, Rational Decision-Making About Marriage and Divorce, 76 V. L. REV. 9 (forthcoming 1990).

Although these are not technically questions of repeating (they concern termination of existing relationships), the concerns that restrict exit from marriage in part reflect those mentioned in support of repeat contracts. Of significance are the reasons given to enforce cooperation: Exit creates costs that are socially unproductive (children will suffer); and the knowledge that exit is difficult will give the parties incentives to work to preserve, rather than flee, the relationship.

123. Personal service contracts, for example, are given special treatment and cannot be specifically enforced because of the fear of the infringement upon human dignity. See supra note 119.

124. Interestingly, while commentators rarely if ever explicitly state this bifurcation, it is often implicit in the examples chosen to illustrate points. Thus, Professor Fried argues that the moral 
Of course, not all contracts will fit easily into one category or the other. Nor is the line a simple one between individuals and businesses. A small business that operates on a personal scale might well act more like a "person" than a business in some cases. Moreover, contracting partners may not be symmetrically placed. Thus, an employee of a large business may invoke humanistic values to breach her employment contract, but the business may not. If the employee's immediate supervisor cannot tolerate her, the business, if sufficiently large, can transfer her elsewhere. But such problems of judgment appear small compared to the price of assuming that all contracts, regardless of party characteristics, are the result of personal concerns; and judgment errors can be minimized by allowing the consideration of humanistic concerns in cases of doubt. ${ }^{125}$

\section{B. Summary: Dealing With the Problem}

To initiate debate upon possible solutions to the problein of repeat contracting, this Part has considered three possible approaches: enforcing negotiated renewal clauses, inplying renewal terms where contracts are silent as to renewal (thus creating opt-out renewal obligations), and, finally, inposing mandatory renewal obligations. Each option has different effects and a different balance of strengths and weaknesses which depends upon the nature of the underlying contract. The foregoing analysis suggests that the optimal strategy for dealing with renewal would be to generate a grid of rules in order to distinguish between and regulate different types of contracts.

Thus, of the three options considered, contracts between sophisticated parties are probably best dealt with either by implying an opt-out renewal term or by enforcing self-imposed renewal clauses. Both options allow sophisticated parties to identify repeat values and to choose their own strategies to deal with their contractual relationships. The choice between these options depends upon their relative costs. My analysis suggests that enforcing contractual renewal terms would be preferable where large renewal values are at stake, while opt-out renewal might be preferable for smaller renewal values, since such cases are less likely to be

basis of contract is respect for individual dignity and relies largely on examples of contracts between people. See supra note 115.

Much of the law and economics literature, on the other hand, which presupposes economic rationality and focuses on the economic efficiency of contract rules, appears to be writing about purely business transactions between economically sophisticated parties. Perhaps what we see is that the moral bases and behavioral assumptions underlying contract depend on the nature of the contract and contracting parties. It is not, then, irrational to have different systems of rules to govern the different types of contract and contracting parties.

125. I prefer to err on the side of considering problems of empowerment and taste because a failure to do so when they are relevant seems to me a more significant cost than the converse. 
worth the costs of consideration at the initial contracting stage. As an exception to the rule of party autonomy in both cases, we might seek to identify classes of contract in which the parties' interests are likely to diverge from the public interest and to impose mandatory repeat obligations in those cases. ${ }^{126}$

Renewal between unsophisticated parties, however, is probably best dealt with by either the opt-out implied renewal regime or a mandatory renewal term. Such parties, who normally would fail to consider renewal at the initial stage, are basically free of renewal obligations under the current system in which renewal obligations must be self-imposed. Contracts between unsophisticated parties are probably best divided into two groups. Those that create significant relational values should be subject to mandatory renewal; and those that have insignificant relational values, or that create obligations of a more personal nature, should be free of renewal obligations.

\section{IV \\ CONCLUSION}

Contract law has for too long pretended that contractual relationslips are mediated through the same time frames as those artificially imposed by contract rules. It has ignored the possibility that relationships created through contractual dealings may continue to have value to tlie parties concerned after the contract itself has ended by its own terms. These continuing relational values can be a source of savings for the parties involved and for society as a whole if the parties continue to deal with each other rather than terminating their relationship and seeking new partners. ${ }^{127}$

Unfortunately, however, the same values also create a fertile ground for opportunistic gamesmanship by the parties, which at best dissipates the savings in negotiation costs, and at worst results in risk-taking strategies that reduce the number of continuing relationships with their attendant savings. Contract law currently mediates contractual relationships as if they commence during the bargaining of a particular contract between the parties and end with the duties prescribed by the contract terms. It therefore ignores tlie problems of opportunism that linger beyond the

126. An exception to this exception should be made where more personal concerns predominate. See supra text accompanying notes 119-25.

127. I am ignoring market problems that might in some cases make it socially preferable that parties shift suppliers, and hence that militate, in some cases, against encouraging repeat transactions even if they result in gains for the immediate parties. A strong incentive or obligation to repeat might, for example, create entry barriers to new suppliers of the goods or services at issue and tend to concentrate the market and render it non-competitive. 
contractual period and imposes no obligations on parties to engage in repeat transactions with their previous partners.

Contracting parties are often powerless to cure the problems generated by the legal failure to recognize continuing relational values. Parties, if they are aware of the nature and quality of the problem at the time they deal initially, may attempt to make the contract and relational values coterminous by writing one contract for the entire period during which they expect their relational dependence to continue. Unfortunately, this practice creates significant problems to the extent that parties do not want to assume future risks. Parties may attempt to mimimize relational opportunism and yet not allocate long-term risks by writing open-ended renewal obligations into their contracts. This strategy is often thwarted by the refusal of courts to enforce renewal clauses that lack certainty. Sophisticated parties with sufficient stake in the problem may attempt to solve the problem by extra-legal sanctioning.

The problems of renewal opportumsm, however, are not limited to such long-term, sophisticated dealings. Many contracts between parties who lack the foresight, knowledge, or the stakes to consider renewal problems at the time of the initial deal will generate relational dependencies that will influence subsequent dealings between the same parties, with the same potential for wasteful opportunism at the renewal phase. In these cases, where the parties either do not foresee the problem or do not consider it cost-effective to plan for the problem initially, it is clear that the parties cannot effect a solution to such problems of opportunism without help from the law.

It can also be seen that where the parties are allowed free rein to devise their own renewal strategies, they will often choose to engage in risk-taking behavior. This may maximize their individual gains through opportunistic tactics, but it also inay lead to socially unproductive results. Repeat contracts that would generate overall savings will be foregone for strategic reasons, as each party attempts to appropriate a larger share of the joint savings.

A more realistic view of contractual relationships and the bargaining process would allow us to identify and devise legal strategies to ameliorate some of the opportunism problems created by relational dependencies. If, for exainple, we can design cost-effective rules that will induce repeat contractimg where residual relational values warrant repeating, we might substantially reduce the costs of relational opportunism. There is little conceptual difficulty with imposing such obligations in situations where parties either cannot, or choose not to, consider the problems of repeat contracting imitially. Where parties have chosen not to repeat, conceptual problems with imposing terms-the fear of 
restricting party autonomy - appear more problematic. For many types of contracts, however, this fear is unjustified.

There are two types of justifications for allowing autonomy in contracting. The first stems from considerations of efficiency. Under certain conditions free trades between parties can be deemed to increase overall value, since we can conclude that each is better off after trading. ${ }^{128}$ Moreover, society is deemed better off since both traders are better off with no one the worse. However, we assume too often that since an autonomous trade has occurred, the desired consequences of autonomous trading have ensued. In many situations autonomous trades occur under conditions which do not result in increased value for both parties ${ }^{129}$ or for society as a whole. In the case of repeat transactions, party opportunism can result in the divergence of increased individual value from increased social value. Here, party autonomy, which might increase party welfare, results in net social losses and is therefore purchased at a social cost. In such cases, it is reasonable to question whether party autonomy is worth its social cost-especially when we are dealing with the supposed autonomous "right" to engage in opportunistic behavior.

The second type of reason justifying autonomy is based upon more humanistic values. We would often prefer to allow parties to indulge private tastes, to limit the time and extent to which they are obliged, against their wishes, to serve others, and to give them a sense of power and control over their destinies and environinent. This type of reason, which could and sometimes should transcend more collective goals, might well depend upon the nature- the extent and invasiveness-of the contractual services. But it must also depend upon the nature of the contracting party. Reasons centered upon individual tastes and feelings must apply only to entities which can be presumed to have such tastes and feelings. In the case of purely business actors, which can be deeined, and whose purpose is defined, to be purely profit maximizing, such humamistic justifications simply should not apply.

All of this suggests that the rules we devise must depend upon the nature of the transaction and the parties to it. We often attempt to discuss contract rules as if the same rules should apply to all parties, and then allow deviation by creating exceptions at the fringes. ${ }^{130}$ But the nature of the transaction (Is it likely to generate relational values? What

128. Otherwise, they would not consent to the trade.

129. For example, information failures or market conditions may prevent friction-free trading, or either or both parties may simply have made a mistake.

130. Another strategy is to act as if the same rule applies while allowing some ambit for differential rules by choosing general rules which are elaborated-as an evidentiary matter-by appeals to the particular situation. Appeals to the "course of dealing" and "usage of trade," for example, strike me as attempts to allow for such particularization under a rubric of general applicability. See, e.g., U.C.C. § 1-205. 
amount? Is repeating likely?) and the parties (Sophisticated or unsophisticated? Profit maximizing or more individualistic?) is crucial to the choice of the appropriate regime. I therefore suggest that we self-consciously engage in attempts to create a more elaborate classification of contracting, and devise grids of rules to apply as appropriate to each situation.

As a first, and by no means exhaustive, step in devising such a grid of rules to deal with the problems of repeat opportunism, I suggest that we should reexamine the current presumption that parties have no obligation to negotiate renewal contracts unless explicitly provided for in the initial contract. The preceding analysis suggests that several factors are important to the choice of appropriate governing rules. ${ }^{131}$ First, are the parties sophisticated with respect to renewal, and did they consider renewal negotiations worthwhile at the initial bargaining stage? Second, is the contractual relationship one that is hikely to generate continuing relational values after the nominal contract termination date? Third, is there a high or low probability of repeating, and what is the value of repeating? Fourth, what are the parties like, and what is the nature of the services for which they contracted? Under such an analysis, the current presumption that contracts are non-renewable unless renewal is expressly provided for can be seen as most appropriate in cases where sophisticated parties, deahing with contracts with sufficiently large repeat values to warrant iintial consideration, are likely to have interests congruent with the larger society. As these constraints are weakened, other legal regimes appear more appropriate for dealing with the problems of repeat contracting.

As an initial attempt to develop such a system of rules to govern repeat contracting, this Article has considered a system of three regirnes. First, we could require that repeat obligations be expressly provided for (the opt-in regime); second, we could imply repeat obligations which may be negated by express party agreeinent (the opt-out regime); and finally, we could impose a regime of mandatory renewal unless excused. Under this system, sophisticated parties are probably best served by an opt-in regime where significant repeat values are likely, and by an opt-out regime where they are not. Mandatory renewal, however, should apply whenever private opportunism is likely to create conflict between individual profit maximization and societal efficiency. Unsophisticated parties are better served by a presumption of renewability. In both cases, contracts in which more personal values predominate should be exempt from renewal obligations.

Undoubtedly, otler and better approaches exist and await elabora-

131. Obviously the extent to which they are important, the extent to which other factors should be considered, and the extent to which the game is worth the candle await further elaboration. 
tion. The discovery of better strategies to control opportunism in repeat contracting, and in contractual relationships in general, however, requires that we recognize and be sensitive to the artificiality of the boundaries imposed on contractual relationships by contract law. 


\title{
California Law Review
}

\begin{tabular}{lll}
\hline \hline VoL. 77 & OCTOBER 1989 & No. 5 \\
\hline \hline
\end{tabular}

Copyright $(\mathcal{C} 1989$ by California Law Review, Inc.

\section{BOARD OF EDITORS}

1989-90

\author{
Editor-in-Chief \\ JOHN TINKHAM \\ Managing Editor \\ JoHN F. CHASE
}

Senior Articles Editor

Steven L. Friedlander

Articles Editors

JULIET BROWNE

LINDA FOY

PATRICIA L. Godsey

Michael Miller

ERIC M. BRoOKS

David B. Feldman

ERIC GRANT

STEVEN HARDY

JON HINCK

DAVID P. HubBard

LIBBY JACOBS

MiRANDA KaNe

NANCY KIM

ANNA MARIE ARMSTRONG

D. CAMERON BAKER

ADAM BATTANI

JAMES E. BAYLES, JR.

MARguerite BuI

EDWIN BURGOS

Paula Chertok

LAURA M. CRASKa

MARIA LISA CRISERA

AUDRA ECKERLE

PAUL EdWARdS

STEVEN ElLis

GAIL ENGSTROM

ANN FOERSCHLER
Senior Executive Editor

JENNIFER UPHAM

Executive Editors

RICHARD E. LEAHY

HELEN SHIN

LAURINE TULEJA

Research \& Topics Editor

KIM THOMPSON

Associate Editors

MARgaret LIN

David McGowan

Clare Maier

MICHAEL MORRISSEY

SCOTT G. PARKER

Maria Rabassa

ROBERT RENNER

STEVEN RINKLE

ROBIN ROGERS

\section{Members}

Bruce D. Gellman

CARL GOLDBERG

JOHN HARTENSTEIN

DEAN M. KaTO

J. MONICA KIM

SCOTT KRONLAND

MARK LEMLEY

LUIS LI

JoHn MacPete

ANDREW MASTIN

CAROLYN F. MCNIVEN

TIMOTHY A. MILLER

ChRISTIAN NADAN

MARTIN NICHOLS

Office Manager

MARY P. Nelson
Senior Note \& Comment Editor

RUSS ELMER

Note \& Comment Editors

Christopher ConNer

MARETA C. HAMRE

NAOMI ROHT-ARRIAZA

Catherine Salton

TAMARA SEYLER-JAMES

ROBERT SILTANEN

JOHN SITHER

MORGAN SMOCK

MARIA ISABEL TAN

MELISSA THOMAS

JANA WINOGRADE

Michael Page

Paul G. Prince

DON SCARAMASTRA

WENDY SCHMIDT

KATE SCHNEIDER

SEAN M. SeLegue

ANDREW SHAGRIN

KIMBERLY SMITH

SID SPAETH

Marta Tanenhaus

RAGESH K. TANGRI

JESSICA C. VAPNEK

TAY C. VIA

NATASHA ZALKIN 
